\title{
ACCESS TO JUSTICE AND THE INSTITUTIONAL LIMITS OF INDEPENDENT COURTS
}

\author{
Micah B. Rankin
}

Canadian citizens' inability to access courts has been a subject of controversy for decades. Despite widespread evidence that Canada's legal aid system is faltering, governments continue to be unwilling to commit the resources necessary to remedy the problem. In the meantime, Canadian courts have failed to develop constitutional standards defining the government's obligations to ensure that Canadians have access to courts. In this paper, the author argues that people's inability to access courts and obtain legal representation not only has implications for their rights and interests, but may also create specific burdens on courts and judges that can sometimes undermine their independence. The author argues that the traditional view of judicial independence is too narrow and should be expanded. Judicial independence, the author claims, is best understood as a variable bundle of rights, guarantees and powers conferred on courts and judges that preserves and enhances their abilities to adjudicate impartially, maintain a constitutional distribution of powers and uphold the rule of law. Since people's inability to access courts and obtain legal representation can impair the judiciary's ability to preserve these values, the author argues that judicial independence is undermined. Relying on his broadened conception of judicial independence, the author claims that it is possible to correct problems of inaccessibility by recognizing that courts have a power to appoint state-funded counsel in appropriate circumstances in order to preserve their independence.

L'incapacité des Canadiens d'avoir accès aux tribunaux est sujet de controverse depuis des décennies. En dépit des nombreuses preuves de l'affaiblissement du système d'aide juridique du Canada, les gouvernements refusent encore d'engager les ressources nécessaires pour remédier au problème. Parallèlement, les tribunaux canadiens n'ont pas réussi à élaborer des normes constitutionnelles qui définiraient

* Faculty of Law, Thompson Rivers University. A substantial portion of this article was originally submitted as my LL.M. thesis at the University of Toronto. I am very grateful to Professor David Dyzenhaus for his kind and patient supervision of my thesis work. I also want to thank Janet Minor and the members of the Ontario Ministry of the Attorney General, Constitutional Law Branch, who were kind enough to invite me to present my research to them. Their comments were greatly appreciated. All errors are my own. 
l'obligation du gouvernement d'assurer aux Canadiens l'accès aux tribunaux. L'auteur du présent article affirme que l'incapacité d'avoir accès aux tribunaux et d'être représenté par un avocat non seulement a une incidence sur les droits et les intérêts des Canadiens, mais aussi impose aux tribunaux et aux juges un fardeau qui, parfois, mine leur indépendance. Il ajoute que l'indépendance juridique est traditionnellement vue d'une manière trop restreinte, et qu'elle devrait plutôt être considérée comme un ensemble variable de droits, de garanties et de pouvoirs qui sont conférés aux tribunaux et aux juges et qui préservent, voire améliorent, leur capacité de rendre des décisions impartiales, de maintenir une répartition constitutionnelle des pouvoirs et de faire respecter la primauté du droit. Étant donné le fait que l'incapacité des Canadiens d'avoir accès aux tribunaux et d'être représentés par un avocat peut nuire à la capacité de la magistrature de préserver ces valeurs, l'auteur soutient qu'il y a atteinte à l'indépendance judiciaire. Se fondant sur sa conception élargie de l'indépendance judiciaire, il affirme qu'on peut corriger les problèmes d'inaccessibilité en reconnaissant aux tribunaux, pour préserver leur indépendance, le pouvoir de nommer des avocats dont les services sont financés par l'État dans les circonstances appropriées.

\section{INTRODUCTION}

Canadians' inability to access courts is a problem that has vexed scholars and policy-makers for decades. At times, it seems that hardly a day passes without a study being released demonstrating that the federal and provincial governments are failing to meet people's legal needs. ${ }^{1}$ But despite a growing consensus that the Canadian legal aid system has faltered, governments remain unwilling to commit the resources necessary to ensure that people's legal needs are met. Meanwhile, courts have regularly declined to impose even modest constitutional obligations on governments that would require them to support access to courts.

In general, the problem of inaccessible courts has been examined by reference to its implications for individual litigants. In this paper, I propose to explore the problem of inaccessible courts by considering how it affects courts and judges. Although a lack of legal representation undoubtedly produces unfairness to litigants, I suggest that it may also pose problems for the judiciary itself. What, for example, are the implications of the increasing number of unrepresented litigants for a judge's capacity to be impartial? Moreover, if people cannot initiate proceedings, what effect does this have on the court's ability to ensure that government exercises its powers in conformity with the rule of law? I will argue that the answers to these and related questions reveal that the government's failure

\footnotetext{
Indeed, in the course of writing this paper a major report was issued in British Columbia detailing the increasingly precarious state of the legal aid system in that Province: Leonard Doust, Foundation for Change: Report of the Public Commission on Legal Aid in British Columbia (Vancouver: Public Commision on Legal Aid, 2011).
} 
to adequately support access to courts undermines courts' and judges' independence.

I begin my discussion by reviewing some of the access to justice problems that currently plague the Canadian legal system. I first consider the concept of access to justice and its rationales, noting that most scholarly accounts of access to justice have focussed on problems of inaccessibility from the perspective of litigants. Following this, I survey some of the empirical evidence demonstrating that Canada's legal system can be described as being in a state of crisis. I conclude Part II by examining the Supreme Court's jurisprudence on the right to state-funded legal counsel under the Charter of Rights and Freedoms. ${ }^{2}$ Based on the current state of the law, I consider it unlikely the Supreme Court will recognize a constitutional right to state-funded counsel unless one adopts a fresh approach to the issue.

In Part III of this paper I discuss the concept of judicial independence. While there is widespread agreement on the importance of having an independent judiciary, there is surprisingly little consensus on how one should go about defining judicial independence. My overall claim is that the traditional view of judicial independence should be rejected. I suggest, instead, that because judicial independence is an instrumental value, the precise rules and guarantees that it entails vary according to the value it is intended to support. For this reason, I also suggest that judicial independence can be likened to a bundle of rights and guarantees conferred on judges and courts that ensure they are capable of adjudicating impartially, maintaining a constitutional separation or distribution of powers and also are able to uphold the rule of law. I conclude Part III by reviewing the Supreme Court of Canada's jurisprudence on judicial independence, which, I argue, broadly conforms to my description of judicial independence.

In the final part of the paper, I draw together the themes from previous two parts arguing that people's inability to access courts or obtain legal representation can sometimes interfere with the judiciary's ability to adjudicate impartially, maintain a separation of powers and uphold the rule of law. Specifically, I maintain that because people are unable to initiate legal proceedings, or must proceed unrepresented, judges are often unable to uphold the three fundamental values I have identified. In my view, this constitutes a threat to the judiciary's independence that can and should be rectified. Relying on my broadened definition of judicial independence, I argue that it is both possible and desirable for courts to recognize that they have a power and sometimes a duty to appoint legal counsel to ensure that problems of inaccessibility do not undermine their independence. My ultimate claim is that judges have a constitutionally entrenched power to appoint state-funded legal counsel when it is necessary for them to support one or more of the values underlying judicial independence. In contrast with existing Charter-based appointment powers, the power to appoint legal representation that I am proposing would not be limited to proceedings involving deprivations of life, liberty or security of the person. Nor would it require state action. Since judges must, in any proceeding, be able to act impartially and uphold the rule of law, there is no reason that their power should be limited to a specific subset of legal disputes.

2 Canadian Charter of Rights and Freedoms, Part I of the Constitution Act, 1982, being Schedule B to the Canada Act 1982 (UK), 1982, c 11 [Charter]. 


\section{ACCESS TO JUSTICE IN CANADA: A LEGAL SYSTEM IN TURMOIL}

\section{A. Access to Justice: The Concept and its Rationales}

Access to justice has become a ubiquitous feature of modern legal discourse. But despite frequent reference to the concept by scholars, courts and policymakers, its meaning remains elusive and reflects "a wide range of different values and objectives in relation to a great diversity of issues and activities." Since many factors affect the relative "accessibility" or "justness" of a legal system, access to justice inevitably corresponds to a variety of different values and objectives. At the same time, the diverse circumstances in which it is invoked sometimes lead to it being treated as little more than a meaningless slogan.

I find it helpful to think of access to justice as a concept that exists on a continuum, with more or less formal conceptions on one side, and substantive conceptions on the other. ${ }^{5}$ Formal conceptions are likely the most familiar and have preoccupied much of the work of law reform commissions. ${ }^{6}$ According to the formal view, access to justice refers to peoples' abilities to have "reasonable and effective access to courts of law and other tribunals and the opportunity to obtain legal services from qualified professionals." Formal accounts, therefore, focus on the background conditions necessary for litigants to engage existing legal processes, including things like court procedures, court-related fees and of course, the availability of lawyers.

Substantive conceptions of access to justice focus on people's ability to obtain substantive justice - that is to say, their ability to achieve a substantive legal outcome. Substantive accounts typically challenge the notion that access to justice can be equated with people's ability to access law. Indeed, many scholars have

3 Ronald Sackville, "Some Thoughts on Access to Justice" (2004) 2 NZJPIL 85 at $85-86$

[Sackville, "Some Thoughts on Access to Justice"].

4 Mary Jane Mossman \& Heather Ritchie, "Access to Justice: A Review of Canadian Legal Academic Scholarship" in Allan C Hutchinson ed, Access to Civil Justice (Toronto: Carswell, 1990 ) at 55 [Mossman \& Ritchie, "Access to Justice"].

5 Macdonald describes access to justice in terms of two separate surrogacies: "a surrogacy of content - from justice to law (or more precisely, from complex justice to legal justice); and a surrogacy of form - from substance to access (again, more precisely, from the outcomes of institutional to the potential for their invocation)": Roderick A Macdonald , "Access to Justice and Law Reform" (1990) 10 Windsor YB Access Just 287 at 290 [Macdonald, "Law Reform”]

6 Patricia Hughes, "Law Commissions and Access to Justice: What Justice Should We Be Talking About?" (2008) 46 Osgoode Hall LJ 773 at 775 [Hughes, "Law Commissions"] (noting that access to justice today includes physical access and requires the removal of barriers through, for example, translation, sign language interpretation, and accommodation of other physical and mental challenges).See also Macdonald, "Law Reform", supra note 5 at 215 - 236; and see Deborah L Rhode, “Whatever Happened to Access to Justice?” (2009) 42 Loy LA L Rev 869 at 873 (Rhode notes that many commissions want to avoid the divisive task of defining justice in substantive rather than procedural terms).

7 This definition was given by Newbury JA. in Christie v British Columbia (AG), 2005 BCCA 631 at para 30.

8 Hughes, "Law Commissions", supra note 6 at 775 (noting that access to justice today includes physical access to courts and requires things like translation, sign language interpretation, and accommodation of other physical and mental challenges); Macdonald, "Law Reform" supra note 5 at $315-336$.

9 William E Conklin, "Whither Justice-The Common Problematic of Five Models of Access to Justice” (2001) 19 Windsor YB Access Just 297 at 297- 298 (Conklin identifies five models as: 
argued that a preoccupation with access to the formal legal processes sometimes detracts from the underlying social problems that interfere with people's ability to obtain justice. ${ }^{10}$ MacDonald, for example, has argued that focussing on access to formal legal machinery has the effect of treating justice like a commodity that can be achieved by removing "interface obstacles." MacDonald maintains that access to justice problems must be approached holistically with a view to achieving social justice and not merely access to law. ${ }^{12}$

The differences between formal and substantive conceptions of access to justice are significant; however, it would be misleading if I left the impression that the differing conceptions represent competing schools of thought. For the most part, substantive conceptions seek to supplement access to the formal legal process with a more comprehensive set of measures intended to make the legal system more responsive to people's legal needs. Such measures include things like substantive law reform, ${ }^{13}$ alternative forms of dispute resolution, ${ }^{14}$ and the recognition of cultural and linguistic barriers to the legal system. ${ }^{15}$ In this sense, one may regard the access to justice continuum as consisting in "service-oriented, individualized strategies" on the one hand, and "more multi-dimensional and integrated approaches" on the other. ${ }^{16}$

The differing conceptions of access to justice are also driven by a shared set of normative imperatives. I would argue that foremost among these is their commitment to upholding the rule of law. ${ }^{17}$ The rule of law is the idea that public power should be exercised by the government authorities "within a constraining framework of public norms, rather than on the basis of their own preferences(...)", I will say much more about how I believe the rule of law relates to access to justice in Part IV. However, the basic idea is that if people are to be ruled by law,

"Pure Proceduralism", "The Sources Thesis", "The Semiotic Model”, "The Social Convention Model" and "The Law and..." Model).

10 Macdonald, supra note 5 at 297.

11 Ibid at 294. See also Roderick A Macdonald, "Access to Justice in Canada Today: Scope, Scale, Ambitions" in J.Bass, Bogart, W.A, Zemans, FH ed, Access to Justice for a New Century: The Way Forward (Toronto: The Law Society of Upper Canada, 2005) at 23 [Macdonald, "Scope, Scale, Ambitions"].

12 Macdonald, "Law Reform", supra note 5 at 294; Macdonald, "Scope, Scale, Ambitions", supra note 11 at $23-24$.

13 Susan Krongold, "Writing Laws: Making Them Easier to Understand" (1992) 24 Ottawa L Rev 495 (explaining the need to test draft legislative documents on readers).

14 See e.g. Trevor CW Farrow, "Dispute Resolution, Access to Civil Justice and Legal Education" (2005) 42:3 Alta L Rev 741 at $746-747$.

15 Hughes, "Law Commissions", supra note 6 at 779.

16 F Bhabha, "Institutionalizing Access-to-Justice: Judicial Legislative and Grassroots Dimensions" (2007) 33 Queen's LJ 139 at 143.

17 Ibid at 154. (Bhabha comments that access to justice forms an integral part of the rule of law in constitutional democracies). See also Hughes, "Law Commissions", supra note 8 at 777; Lorne Sossin, "The Public Interest, Professionalism and Pro Bono Publico" (2008) 46 Osgoode Hall LJ 131 at 138.

18 Jeremy Waldron, "The Concept and the Rule of Law" (2008) 43 Ga L Rev 1 at 3 [Waldron, "Concept"]. 
it is essential not only that they be able to understand their legal entitlements, but also that they be able to rely on the law to guide and manage their affairs. ${ }^{19}$

Another value the differing conceptions of access to justice share is a commitment to ensuring that citizens are able to participate in the process of legal governance. In this view, participation itself is seen as a kind of social good. ${ }^{20}$ Sommerland, for instance, argues that accessing law is "fundamental to social participation and, for marginalized groups, confers (adult) personhood in the eyes of society at law." ${ }^{21}$ In this sense, people's inability to access courts not only denies them a specific legal remedy, but also deprives them of the opportunity to participate in the process of governance.

A third value often associated with access to justice is equality. ${ }^{22}$ Much of the access to justice scholarship emphasizes how inaccessible courts and the inadequate provision of legal representation can perpetuate inequalities based, among other things, on poverty, race and gender. ${ }^{23}$ Although problems of inaccessibility are felt widely throughout Canada, it is generally recognized that such problems are more acute for marginalized groups. ${ }^{24}$ One of the implications of this is that persons who already suffer from discrimination have little or no recourse to the legal mechanisms that might correct the discrimination they face.

As the above indicates, there is much more that unifies formal and substantive conceptions of access to justice than divides them. I suggest that one other notable feature of much of the access to justice scholarship is that it focuses on problems of inaccessibility from the standpoint of the litigants. Since the value of any system of law ultimately depends upon its implications for individuals, it is understandable that the academic literature has focused on individuals. At the same time, it seems to me that much of the scholarship has neglected to examine how problems of inaccessibility may implicate or affect courts and judges. As I will argue in subsequent parts, although problems of accessibility have important consequences for individual litigants, they may also have broader implications for courts' and judges' abilities to manage Canada's system of law.

19 Janice Gross Stein \& Adam Cook, "Speaking the Language of Justice: A New Legal Vernacular" in J Bass, Bogart, WA \& Zemans, FH ed, Access to Justice for a New Century: The Way Forward (Toronto: The Law Society of Upper Canada, 2005) (commenting on John Rawls' idea of fairness and its relationship to access to justice). See also Joseph Raz, "The Rule of Law and its Virtue" (1977) 93 Law Q Rev 195 at 203 (incorporating a requirement for accessible courts in his positivistic account of the rule of law).

20 Michael Fenrick, "Habermas, Legal Legitimacy, and Creative Cost Awards in Recent Canadian Jurisprudence" (2007) 30 Dalhousie LJ 165 (drawing on Habermas, Fenrick offers an instrumental account of why accessible legal institutions are necessary from the standpoint of communicative reason).

21 Hilary Sommerland, "Some reflections on the Relationship between Citizenship, Access to Justice and the reform of Legal Aid" (2004) JL \& Soc Pol'y 442 at 445 - 6.

22 Mary Jane Mossman, "Shoulder to Shoulder: Gender and Access to Justice" (1990) 10 Windsor YB Access Just 351 [Mossman, "Shoulder to Shoulder"]. See also B Etherington, "Promises, Promises: Notes on Diversity and Access to Justice" (2000) 26 Queen's LJ 43.

23 Kerri A Froc, "Is the Rule of Law the Golden Rule? Accessing "Justice" for Canada's Poor" (2008) Can Bar Rev 459 at 461;. See also Janet Mosher, "Poverty - A Case Study" in Report of the Ontario Legal Aid Review: A Blueprint for Publicly Funded Legal Services (Toronto: Ontario Legal Aid Review, 1997) at 915; PA Monture-Okanee \& ME. Turpel, "Aboriginal Peoples and Canadian Criminal Law: Rethinking Justice" (1992) 26 UBC L Rev 239.

24 Mauro Cappelletti \& Bryant Garth, "Editorial” (1980) 1 Windsor YB Access Just vi. 


\section{B. The Crisis of Legal Representation in Canada}

That successive Canadian governments have failed to adequately fund legal aid is not, in my estimation, a particularly controversial claim. Indeed, people's inability to secure legal representation has been a subject of concern for decades, if not centuries. ${ }^{25}$ Prior to the Second World War, "legal aid" in Canada was largely viewed as a professional responsibility of lawyers to provide pro bono legal services to those who could not afford them. ${ }^{26}$ In the early 1950 s, certain jurisdictions took the first tentative steps toward institutionalizing legal aid. ${ }^{27}$ However, it was not until the 1960s and early 1970s that governments created the first modern legal aid systems. Over time, these legal systems have expanded to include legal aid clinics and a variety of programmes designed to disseminate greater legal information to the public.

From the standpoint of service delivery, Canada's legal aid systems have remained remarkably stable since the 1970s. At present, each of the provinces and territories has its own legal aid system, and all receive a mixture of funding from the federal and provincial governments. ${ }^{28}$ Although the particulars differ in each jurisdiction, they are largely built around two types of service model: the judicare and the staff-lawyer model. ${ }^{29}$ The judicare model refers to a service-delivery model in which private lawyers are paid on a tariff to assist low income clients; by contrast, under the staff-lawyer model, lawyers are employed by an independent statutory commission. In each case, the responsible legal aid commission adopts low income cut-off guidelines that define the types of legal disputes for which funding is available.

Although the service delivery models have changed very little over the years, one aspect of Canada's legal aid systems that has changed significantly is the level of funding provided by government. Legal aid in Canada has always been underfunded; ${ }^{30}$ however, beginning in the 1990 s, the federal government began significantly reducing its contributions to the various provincial and territorial legal aid schemes. In the meantime, however, demand for legal services grew dramatically leading to a major funding gap. At first, provincial legal aid authorities attempted to address these funding shortfalls by finding greater efficiencies in the system. Later, these same authorities simply capped funding regardless of actual demand for legal services. Although funding has grown in some provinces, no legal system in Canada has fully recovered from the historic federal funding cuts. The result is that Canada's legal aid systems have been caught in "a vicious downward spiral.",

\footnotetext{
25 James A Brundage, "Legal Aid for the Poor and the Professionalization of Law in the Middle Ages" (1988) 9 J Legal Hist 169 (Brundage cites evidence suggesting that ecclesiastical advocates had a duty to serve the poor as early as the twelfth century.).

26 Dieter Hoehne, Legal Aid in Canada (Toronto: E. Mellen Press, 1989) at $10-25$.

$27 \quad$ Ibid at 32.

28 Melina Buckley, "Moving Forward on Legal Aid - Research on Needs and Innovative Approaches in Canada" (Report to the Canadian Bar Association, 2009) at 4.

29 A Currie, "Legal Aid Delivery Models in Canada: Past Experience and Future Developments" (Ottawa Department of Justice Canada, 1998) at 2-5.

30 Hoehne, supra note 26 at $78-87$; Buckley, supra note 28 at $4-5$.

31 Michael Trebilcock, Ontario, Ministry of the Attorney General, Report of the Legal Aid Review 2008 (Toronto: Ministry of the Attorney General, 2008) at 74.
} 
The main effect of this legal aid funding gap has been a massive increase in unmet legal need throughout the country. While measuring legal need is not an easy task, ${ }^{32}$ studies have demonstrated high levels of unmet legal need in every area of law. ${ }^{33}$ Traditionally, legal aid funding has been more consistent for criminal law matters; nevertheless, a number of empirical studies have shown that criminal legal aid is seriously deficient, particularly for pre-trial proceedings. ${ }^{34}$ Unmet legal need is even greater in civil proceedings, especially as regarding economic and administrative matters for which little or no government funding is available. ${ }^{35}$

One of the visible consequences of the current legal aid shortfall is the growing number of unrepresented litigants in courts. ${ }^{36}$ Although no nationwide survey has been conducted measuring the number of proceedings involving unrepresented litigants, several smaller scale provincial studies have produced data showing that as many as $50 \%$ percent of proceedings involve one or more unrepresented litigants. ${ }^{37}$ These studies have consistently noted that unrepresented litigants have serious difficulties with the process, prolong court proceedings, frustrate judges and generally increase the cost of litigation and administrative burden on courts.

\section{The Constitutional Right to State-Funded Legal Counsel}

In view of the government's failure to adequately fund legal aid, it should come as no surprise that the right to state-funded legal counsel has been the subject of considerable litigation in the courts. In particular, since the advent of the Charter in 1982, a number of constitutional challenges have been launched under sections 7, 10(b), 11(d), 15 (1) of the Charter in an effort to prompt courts to recognize a constitutional right to lawyers. Although there have been some notable successes over the years, the Supreme Court's overall response to Charterbased claims has been underwhelming.

In the early period following the adoption of Charter, many pinned their hopes on the Supreme Court recognizing a right to state-funded counsel under section

32 Liz Curran \& Mary Anne Noone, "The Challenge of Defining Unmet Legal Need" (2007) 21 JL \& Soc Pol'y 63.

33 For example, according to one recent survey, $47.7 \%$ of low to moderate income Canadians experienced one or more "judiciable" legal problems during the three-year reference period. See A Currie, Unmet Need for Criminal Legal Aid: A Summary of Research Results (Ottawa: Justice Canada, 2003) online : Department of Justice, Canada <http://www.justice.gc.ca/eng/pi/rs/reprap/2003/rr03_la9-rr03_aj9/toc-tdm.html> [Currie, "Unmet Need"].

34 Ibid (Currie provides a comprehensive summary of existing research).

Buckley, supra note 28 at 12 . See also Lenore Woodward et al, Women's Rights to Public Legal Representation (Manitoba Association of Women and the Law, 2002); Lisa Addario, Getting a Foot in the Door: Women, Civil Legal Aid and Access to Justice (Ottawa: Status of Women Canada, 1998).

36 Some scholars distinguish between the "unrepresented" and the "self-represented". The difference is that the unrepresented want to have a lawyer but can not afford one, whereas the "selfrepresented" can afford a lawyer but have chosen not to have one. For the purpose of this paper, the term "unrepresented" is used to collectively refer to any litigant who does not have a lawyer, but who would like to have one.

See e.g. Mary Stratton, Alberta Self-Represented Litigants Mapping Project: Final Report (2007) online: Canadian Forum on Civil Justice <http://cfcj-fcjc.org/docs/2007/mapping-en.pdf>; Nova Scotia Department of Justice, Self- Represented Litigants in Nova Scotia: Needs Assessment Study (Halifax: Department of Justice, 2004); Gayla Reid, Donna Senniw \& John Malcolmson, Developing Models for Coordinated Services for Self-representing Litigants: Mapping Services, Gaps, Issues and Needs (Vancouver: Law Courts Education Society of BC, 2004). 
10(b) of the Charter. That section guarantees that "[e]veryone has the right on arrest or detention...to retain and instruct counsel without delay and to be informed of that right." ${ }^{38}$ In the early decision of Brydges, ${ }^{39}$ the Supreme Court hinted that an accused had a "right to have access to counsel free of charge where the accused meets certain financial criteria set up by the provincial Legal Aid plan." However, the idea that section 10(b) might contain a right to state-funded counsel was definitively rejected in the Supreme Court's 1994 decision in Prosper. $^{41}$ There, the Supreme Court explained that such a right had been contemplated in some of the early drafts of the Charter but was ultimately rejected by its framers. Since its decision in Prosper, the Supreme Court has consistently held that section 10(b) does not create a constitutional right to state-funded counsel, but only requires that an accused be informed of, and have the opportunity to exercise, his or her right to retain and instruct counsel.

Sections 7 and 11(d) of the Charter have together been held to provide a modest right to stated-funded counsel in criminal proceedings where trial fairness might otherwise be compromised. Section 7 protects the "right to life liberty and security of the person" whereas section 11(d) ensures that "[a]ny person charged with an offence has the right...to a fair and public hearing by an independent and impartial tribunal." ${ }^{44}$ In Rowbotham, ${ }^{45}$ the Ontario Court of Appeal held that sections 7 and 11(d) of the Charter permitted trial judges to order a stay of proceedings until state-funded counsel was provided to a criminal accused. ${ }^{46}$ Importantly, however, the Court held that the Charter did not "constitutionalize the right of an indigent accused to be provided with funded counsel." ${ }^{47}$ Rather, "in cases not falling within provincial legal aid plans, sections 7 and 11(d) of the Charter...require[d] funded counsel to be provided if the accused wishes counsel, but cannot pay a lawyer, and representation of the accused by counsel is essential to a fair trial." ${ }^{48}$

Although the Rowbotham decision has subsequently been applied in numerous cases, its overall implication for the problem of inadequate legal representation has been muted. For one thing, before a trial court can appoint counsel, a claimant must demonstrate that legal aid is unavailable; that he or she is impecunious; and that the proceeding is complex enough that trial fairness might be compromised without the assistance of a lawyer. ${ }^{49}$ Moreover, because the Rowbotham power

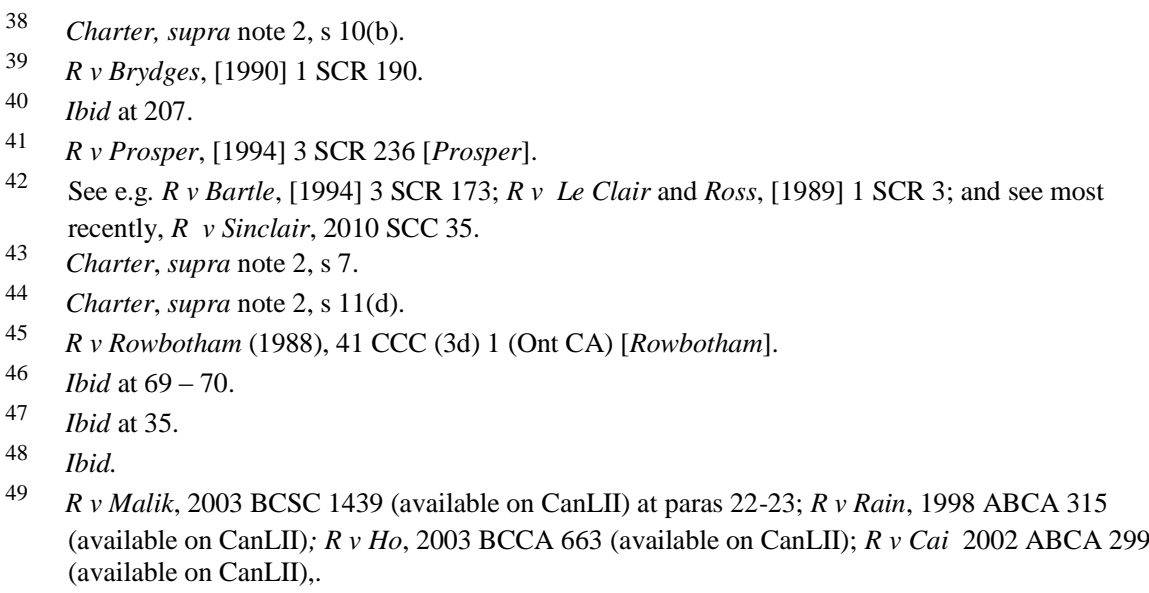


can only be exercised on a case-by-case basis, it has not prompted change on a systemic level. Finally, since the application of the Charter is only triggered by "state action", courts have declined to apply the Rowbotham appointment power in civil proceedings which, as I discussed above, represent the most significant areas of unmet legal need.

The one exception to this last observation is child apprehension proceedings. In New Brunswick (Minister of Health and Community Services) v. G.J., ${ }^{52}$ the Supreme Court ruled that in certain circumstances the suspension of a parent's custody over his or her children could unfairly violate that individual's section 7 rights if that individual were forced to proceed unrepresented. In reaching this conclusion the Court explained: "Without the benefit of counsel, the appellant would not have been able to participate effectively at the hearing, creating an unacceptable risk of error in determining the children's best interests and thereby threatening to violate both the appellant's and her children's section 7 right to security of the person." ${ }^{53}$ As with Rowbotham, the Supreme Court was at pains to limit the scope of its ruling and stated that "a parent need not always be represented by counsel in order to ensure a fair hearing."

The last section of the Charter that has been advanced as potentially supporting a right to state-funded counsel is section 15(1). Section 15(1) of the Charter provides that: "[e]very individual is equal before and under the law and has the right to the equal protection of the law without discrimination and, in particular, without discrimination based on race, national or ethnic origin, colour, religion, sex, age or mental or physical disability." Certain scholars have argued that women might be able to advance a gender-based equality claim because of the different amounts of legal aid funding given to men versus women. ${ }^{56}$ Specifically, because men are charged more often with criminal offences, they receive, as a group, a greater overall portion legal aid funding. The argument, in short, is that

50 Section 32 of the Charter, supra note 2 provides that it applies to "Parliament and government of Canada and to the legislatures and government of each province." The Supreme Court in RWDSU v Dolphin Delivery Ltd., [1986] 2 SCR 573 held that the Charter was intended to control "state actions" and could not be directly invoked to provide relief in "purely private disputes".

51 See e.g. PC v. CG, 2007 NBQB 355, 47 RFL (6th) 399 (PC cited to NBQB); DeFehr v DeFehr, 2002 BCCA 139, [2002] BCJ No 418 (DeFehr cited to BCCA); Ryan v Ryan, 2000 NSCA 10, [2000] NSJ No 13 (QL) (Ryan cited to NSCA). Also see Miltenberger v Braaten, 2000 SKQB 443, [2000] SJ No 59 (Miltenberger cited to SKQB); Hawkes $v$ Prince Edward Island (Human Rights Commission), 2007 PESCAD 1, 794 APR 115 (Hawkes cited to PESCAD); Pavlis v HSBC Bank Canada, 2009 BCCA 450, [2010] 1 WWR 208 (Pavlis cited to BCCA); PD v British Columbia, 2010 BCSC 290; Lacey v British Columbia, [1999] BCJ No 3168 (SC) at para 6; New Brunswick (Minister of Health and Community Services) v. G(J.), [1999] 3 SCR 46 [GJ.] Ibid at 86 .

Ibid at 87.

Charter, supra note 2, s 15(1).

For a summary of the main strands of argument, see Patricia Hughes, "The Gendered Nature of Legal Aid" in Frederick Zemans, Patrick Monahan \& Aneurin Thomas, eds, A New Legal Aid Plan for Ontario: Background Papers (North York, Ontario: York University Centre for Public Law and Public Policy, 1997) 52; Mary Jane Mossman with Cindy L Baldassi, "A Constitutional Right to Civil Legal Aid in Canada" in Vicki Schmolka eds, Making the Case: The Right to Publicly-Funded Legal Representation in Canada (Ottawa: Canadian Bar Association, 2002) 149; Mary Jane Mossman with Karen Schucher \& Claudia Schmeing, "Comparing and Understanding Legal Aid Priorities: a Paper Prepared for Legal Aid Ontario" (2010) 29 Windsor Rev Legal \& Soc Issues 149 at $187-188$. 
provincial legal aid plans have been arranged in a way that protects the interests of men rather than women and are, in this sense, discriminatory. Although the Supreme Court has never squarely addressed this kind of equality argument, I am sceptical that it could succeed. To make out an equality claim, a complainant must demonstrate some kind of distinct treatment based upon an enumerated or analogous ground in the Charter (i.e., race, national or ethnic origin, colour, religion, sex, age or mental or physical disability). ${ }^{57}$ As a matter of doctrine, I think it is unlikely that a court would find that the government had drawn a distinction between men and women based upon the total sums that each group receives in relation to different kinds of legal disputes. Since men and women each have equal access to legal aid for the same type of proceeding, I expect the courts would find they were treated equally for Charter purposes.

For related reasons, I am also sceptical that an equality-based claim could, as some have argued, ${ }^{58}$ succeed on the basis of poverty. For the most part, Canadian courts have refused to recognize that a person's economic status is legally relevant for Charter purposes. ${ }^{59}$ Although the Supreme Court has not directly addressed any poverty-based section 15 claims, lower courts have explicitly rejected the idea that poverty is analogous to race, religion, gender or the other enumerated grounds in the Charter. In Banks, for instance, the Ontario Court of Appeal stated that "[w]hile the 'poor' undoubtedly suffer from disadvantage, without further categorization, the term signifies an amorphous group, which is not analogous to the grounds enumerated in s. 15." ${ }^{60}$ Lower courts have reached similar conclusions in cases bearing more directly on access to justice. In Pleau v. Nova Scotia, ${ }^{61}$ for example, the Nova Scotia Supreme Court rejected a claim that certain court hearing fees violated the section 15 rights of indigent persons because the fees did not account for the differential they had on their ability to access courts. Similarly, in Polwesky v. Home Hardware Store, ${ }^{62}$ the Ontario Divisional Court gave short shrift to a claim that Small Claims Court fees violated the applicant's equality rights, explaining that poverty was not an analogous ground under section 15(1).

The rule of law is the only non-Charter based constitutional principle that has been advanced in support of a right to state-funded counsel. Over the years, discussions about the relationship between the rule of law and access to justice have from time to time cropped in the jurisprudence. ${ }^{63}$ The most important decision, in this regard, was British Columbia Government Employees' Union v.

57 Withler $v$ Canada $(A G), 2011$ SCC 12 at paras $61-67$.

58 See e.g. Mosher, supra note 23 at 913-957; Patricia Hughes \& Joseph Arvay, “A Constitutional Right to Civil Legal Aid" in Vicki Schmolka, Making the Case: The Right to Publicly-Funded Legal Representation in Canada (Ottawa: Canadian Bar Association, 2002).

59 Gosselin v. Quebec (AG) [2002] 4 SCR. 42.

$60 R v$ Banks, 2007 ONCA 19 (CanLII) at para 104. Also see Falkiner v Ontario (Ministry of Community and Social Services) (2002), 59 OR (3d) 481 (CA) at paras 84 - 95 [Banks].

61 Pleau v Nova Scotia (Supreme Court, Prothonotary), [1998] NSJ No 526 at para 104 [Pleau].

62 Polwesky v Home Hardware Store (2003), 66 OR (3d) 600, [2003] OJ No 2908 ( Polwesky cited to Ont SCJ) at paras $45-54$ [Polwesky].

63 See e.g. Pleau, supra note 61; Polwesky, supra note 62. Also see John Carten Personal Law Corp $v$ British Columbia (AG), [1998] 3 WWR 571, 153 DLR (4th) 460 at para 85 (BCCA) [John Carten]; Canadian Bar Assn v British Columbia (AG), (1994) 91 BCLR (2d) 207 [Canadian Bar Assn]; Lawrence v British Columbia (AG), 2003 BCCA 379, 184 BCAC 26 [Lawrence]. 
British Columbia (Attorney General). ${ }^{64}$ In that case, the Chief Justice of the British Columbia Supreme Court acted on his own motion to enjoin striking court workers from setting up picket lines outside of the law courts during a lawful strike. In upholding the injunction, the Supreme Court of Canada explained that the rule of law would be threatened if access to courts was not secure. ${ }^{65}$ As Chief Justice Dickson opined: "[I]t would be inconceivable that Parliament and the provinces should describe in such detail the rights and freedoms guaranteed by the Charter and should not first protect that which alone makes it in fact possible to benefit from such guarantees, that is, access to a court."

Any hope that the rule of law might support a right to state-funded legal counsel was dashed in the Supreme Court's decision in British Columbia (Attorney General) v. Christie. ${ }^{67}$ At issue in Christie was the constitutionality of a tax that applied to legal services in British Columbia and which had long been a source of constitutional litigation in the Province. ${ }^{68}$ The claimant, Mr. Dugald Christie, a well-known poverty law activist, argued that the tax violated the rule of law because it interfered with his ability to deliver low cost civil legal aid services and therefore, created an unreasonable barrier to low income persons' ability to access courts. $^{69}$ Although Christie's claim succeeded in the lower courts, ${ }^{70}$ the Supreme Court allowed the appeal holding (unanimously) that "a review of the constitutional text, the jurisprudence and the history of the concept does not support the respondent's contention that there is a broad general right to legal counsel as an aspect of, or precondition to, the rule of law.",11

The Supreme Court's holding in Christie was disappointing on a number of fronts, but especially because of the Court's seemingly narrow interpretation of the rule of law. ${ }^{72}$ Although the Court in Christie held that its decision did not "foreclose on the possibility that a right to counsel may be recognized in specific and varied situations," ${ }^{73}$ the thrust of its reasoning was that such a right could not be supported by the rule of law. Indeed, recent lower court decisions have interpreted Christie as foreclosing on any rule of law-based requirement for statefunded legal counsel. ${ }^{74}$ Although it is possible that the Supreme Court may change its course, I am doubtful it will do so unless it is presented with a fresh approach to the problem of unrepresented litigants.

What would such a fresh approach look like? In virtually all of the cases I have reviewed, the problem of inaccessible courts and the inadequate provision of

\footnotetext{
64 British Columbia Government Employees' Union v British Columbia (AG), [1988] 2 SCR 214 [BCGEU].

65 Ibid at 228.

66 Ibid at 229.

67 British Columbia (AG) v. Christie, [2007] 1 SCR 873 [Christie].

68 See e.g. Canadian Bar Assn, supra note 63; John Carten supra note 63; Lawrence, supra note 63.

69 Christie, supra note 67 at para 5.

70 Christie v British Columbia (AG), 2005 BCSC 122; aff'd 2005 BCCA 631.

71 Christie, supra note 67 at para 23.

72 Mark Carter, "The Rule of Law, Legal Rights in the Charter, and the Supreme Court's New

Positivism" (2007-2008) 33 Queen's LJ 453. Also see Froc, supra note 23.

Christie, supra note 67 at para 27.

74 Canadian Bar Association v British Columbia (AG), 2006 BCSC 1342, 59 BCLR (4th) 38; aff'd 2008 BCCA 92.
} 
legal aid has been examined from the standpoint of individual litigants' rights and interests. Although there is a great deal to be said for approaching the problem in this way, it seems to me that it is unlikely that any lower court will be prepared to redefine the scope of existing Charter rights without new direction from the Supreme Court. One dimension of the problem that has not been considered is whether people's inability to access courts or obtain legal representation somehow interferes with courts' and judges' abilities to uphold some of the fundamental values underlying Canada's system of law. It seems to me that courts may be more willing to take steps to address problems of inaccessibility if they viewed them as undermining the judiciary's ability to maintain integrity of the legal system.

\section{THE CONCEPT AND SOURCES OF JUDICIAL INDEPENDENCE}

\section{A. The Divergent Approaches to Judicial Independence}

With its roots stretching back to the Glorious Revolution of 1689, judicial independence is one of Canada's most cherished constitutional values. At its most basic, the concept of judicial independence refers to the idea that judges must be able to make decisions impartially, according to law, and without fear of personal, economic or political reprisal. ${ }^{75}$ Yet despite the simplicity of this proposition, judicial independence is a concept that is often "easier to salute reflexively than to grasp fully." parameters of judicial independence remain hotly contested. Some scholars have even gone as far as claiming that judicial independence is no longer "a useful analytic concept.",

There is no single "literature" on judicial independence. ${ }^{78}$ However, in my view, two main approaches are discernable in the scholarship. ${ }^{79}$ The first approach, known as Interactionalism, defines judicial independence as the measurable product of interactions between governmental institutions within a

75 Archibald Cox, "The Independence of the Judiciary: History and Purposes" (1995) 21 U Dayton L Rev 565 at 566 [Cox].

76 Linda Greenhouse, "Independence: Why \& from What?" (2008) 137 Daedelus 5 at 5.

77 Lewis A Kornhauser, "Is Judicial Independence a Useful Concept?" in Stephen B Burbank \& Barry Friedman eds, Judicial Independence at the Crossroads: An Interdisciplinary Approach (Thousand Oaks: Sage Publications Inc, 2002) 45 (Kornhauser maintains that discussions about the definition and meaning of judicial independence have obfuscated what should be the primary concern of scholars; namely, the actual performance of courts and judges in practice).

78 Stephen B Burbank, "Introduction" in S B Burbank \& B Friedman eds, Judicial Independence at the Crossroads: And Interdisciplinary Approach (Thousand Oaks: Sage Publishers Inc, 2002) 1 at 5 [Burbank, "Introduction"].

79 Lydia B Tiede, "Judicial Independence: Often Cited, Rarely Understood” (2006) 15 J Contemp Legal Issues 129115 - 155 (Tiede argues for a tripartite organization which divides the scholarship between Institutionalist, Judicial Rulings Against Government and Strategic Interactionalist approaches. My view is that the latter two involve substantially similar approaches to judicial independence because they describe it in terms of institutional outputs rather than institutional in-puts.). Also see Janice Gross Stein, "Going Too Far, Too Fast: Judicial Independence and Political Judgment" in Adam M Dodek \& Lorne Sossin eds, Judicial Independence in Context (Toronto: Irwin Law Inc, 2010) 580 at 583 (adopting Tiede's tripartite division). 
given nation-state. ${ }^{80}$ For Interactionalist scholars, judicial independence should not be defined by the presence or absence of specific constitutional mechanisms. Tiede, for instance, argues that definitions of judicial independence must not contain "too many facets or requirements." For Interactionalists, judicial independence is a state of affairs that obtains when judges and courts are able to exercise coordinate power in relation to other organs of a state. For this reason, Interactionalist scholars argue that judicial independence "can and should be defined as the judiciary's independence from the executive as measured by the amount of discretion that individual judges exercise in particular policy areas."

The second major approach to judicial independence is the Institutionalist approach. In contrast with Interactionalist scholars, Institutionalists focus on how institutional arrangements can "advance or inhibit judicial independence." size and complexity of the Institutionalist scholarship makes it impossible to review it in any detail. However, one notable trend in the Institutionalist literature is a tendency to define judicial independence according to complicated and eversubtler sub-categorizations. Some of the examples include: "institutional independence", 85 "decisional independence", "counter-majoritarian independence", "lawmaking independence", "structural independence", "collective independence", "personal independence", and "external" and "internal independence". 92

80 Burbank, for instance, argues that at its core, judicial independence is a particular set of outcomes that flow from the structural features of government. See Stephen B Burbank, "The Architecture of Judicial Independence" (1998) 72 S Cal L Rev 315 at 317 [Burbank, "The Architecture"]. Also see McNollgast, "Conditions for Judicial Independence" (2006) 15 J Contemp Legal Issues 105 at 106. Law and Economics scholars emphasize interactions between interest-groups and so I would include them as part of the Interactionalist scholarship. See e.g. William M Landes \& Richard A Posner, "The Independent Judiciary in an Interest-Group Perspective" (1975) 8 JL \& Econ 875; E Salzberger \& P Fenn, "Judicial Independence: Some Evidence from the English Court of Appeal" (1999) 42 JL \& Econ 831.

81 Tiede, supra note 79 at 135 . Also see McNollgast, ibid at 108.

82 Tiede, supra note 79 at 137

83 Ibid.

84 Stein, supra note 79 at 583.

85 Francis K Zemans, "The Accountable Judge: Guardian of Judicial Independence” (1998) 72 S Cal L Rev 625 at 630 (discussing institutional versus decisional independence).

86 Martin H Redish, "Federal Judicial Independence: Constitutional and Political Perspectives" (1994) 46 Mercer L Rev 697 ; Joseph Hood, "Judicial Independence” (2003 - 2004 ) 23 J Nat'1 Ass'n Admin L Judges 127 at 139; G Wheeler \& R Bermant, "Federal Judges and the Judicial Branch: Their Independence and Accountability" (1995) 46 Mercer L Rev 835 at 836 (identifying different levels of independence, including decisional independence, personal independence, procedural independence, administrative independence; and different levels of accountability, namely internal versus external accountability).

87 Joseph H Rodriguez, "New Threats to Judicial Independence" (1996) 35 Judges J 27 at 27. Also see Redish, supra note 86 at 698.

88 Zemans, supra note 85 at 630.

89 David Pimentel, "Reframing the Independence v Accountability Debate: Defining Judicial Structure in Light of Judges' Courage and Integrity" (2009) 57 Clev St L Rev 1 at 5 [Pimentel]; and see CG Geyh, "Straddling the Fence Between Truth and Pretense: The Role of Law and Preference in Judicial Decision Making and the Future of Judicial Independence" (2008) 22 Notre Dame JL Ethics \& Pub Pol'y 435 at 441. 
Despite the differences between the two main approaches to judicial independence, the debates within and between them arguably orbit around a relatively stable set of disagreements. The first concerns whether there are minimal conditions and mechanisms that must be in place in order for the judiciary to be independent. For some scholars, judicial independence requires, at a minimum, that judges possess secure tenure and that they have some form of financial security. ${ }^{93}$ Other scholars claim that judicial independence may only require life tenure. ${ }^{94}$ Still others maintain that for the judiciary to be independent it is necessary that judicial appointments be made according to a transparent process. ${ }^{95}$ A second set of disagreements concerns technical questions about the optimal way of implementing the rules and guarantees relevant to judicial independence; that is to say, assuming there are minimal conditions, what is the best way to implement these conditions? Finally, many of the debates in the scholarship focus on how to balance independence with accountability. ${ }^{96}$

The above provides only a glimpse into the debates surrounding the meaning of judicial independence. My own view is that because of its nature, the concept of judicial independence is open to endless debate and disagreement. ${ }^{97}$ For one thing, I suggest the very idea of "independence" is itself ambiguous. Who, for example, is supposed to be independent? Is it judges or courts? Moreover, practically speaking, a complete separation between courts, judges and the state seems to be impossible and likely undesirable.

\section{B. Judicial Independence as a Bundle of Rights and Guarantees}

In view of the divergent approaches to judicial independence, it is no wonder there are doubts about its utility as an analytic concept. However, I would argue that responding to these doubts does not, as some have suggested, ${ }^{99}$ require that we abandon the concept altogether. Despite its many conceptual vicissitudes, the

$91 \quad$ Ibid at 76.

92 Ibid at $77-78$.

93 MJLJ King, "Minimum Standards of Judicial Independence" (1984) 58 Austl LJ 340 at 343. Also see TE Plank, "The Essential Elements of Judicial Independence and the Experience of Pre-Soviet Russia" (1996) 5 Wm \& Mary Bill Rts J 1 at 6 - 34

94 See Burbank, "Introduction", supra note 80 at 10.

95 For a summary of this debate see: Charles G Geyh, "The Endless Judicial Selection Debate and Why It Matters for Judicial Independence" (2008) 21 Geo J Legal Ethics 1259. See also FC Decoste, "Political Corruption, Judicial Selection And The Rule Of Law" (2000) 38 Alta L Rev 654; Michael Bryant, "Judging the Judges: Judicial Independence and Reforms to the Supreme Court of Canada Appointment Process" (2004) 24 Sup Ct L Rev 29; KD Ewing, "A Theory of Democratic Adjudication: Towards a Representative, Accountable and Independent Judiciary" (2000) 38 Alta L Rev 708.

96 See e.g. PD Carrington, "Judicial Independence and Democratic Accountability in Highest State Courts" (1998) 61 Law \& Contemp Probs 79 at 85.

97 It may be that judicial independence is an essentially contested concept. See WB Gallie, "Essentially Contested Concepts" (1955) 56 Proceedings of the Aristotelian Society 167. Gallie's argument was that while some disputes over concepts result from miscommunication or imprecision, certain concepts "inevitably involve(...) endless disputes about their proper uses [which] are perfectly genuine: which, although not resolvable by argument of any kind, are nevertheless sustained by perfectly respectable arguments and evidence." Whether judicial independence meets the strict letter of Gallie's criteria is perhaps debatable.

98 Carrington, supra note 96 at 87.

99 Kornhauser, supra note 77 at 47. 
notion that a constitutional order requires an independent judiciary is deeply engrained in the idea of constitutionalism itself. ${ }^{100}$ Moreover, while I accept judicial independence poses a number of analytical difficulties, there are, I think, certain features of the concept that make it both meaningful and manageable.

One of the first things I think is important about judicial independence is that it is an instrumental concept; ${ }^{101}$ by this, I mean no more than that an independent judiciary is a means to an end and not an end in itself. Although virtually every account of judicial independence acknowledges that it is an instrumental concept, the various attempts at developing a uniform definition of judicial independence indicate to me that many scholars have not internalized the implications of its instrumental nature. Most significantly, I suggest that because judicial independence is an instrumental concept, deciding which rules and guarantees it requires depends upon the value it is supposed to support. In general, judicial independence has been said to support three more fundamental values: impartiality, ${ }^{102}$ the maintenance of a constitutional separation or distribution of powers, ${ }^{103}$ and the rule of law. ${ }^{104}$

A second distinguishing feature of judicial independence is that it is a relational concept. As Russell explains, it "refers to the important features of the relationship that the judiciary as an institution ought to have with other parts of the political system, and also of the relationship that members of the judiciary ought to have with one another." ${ }^{105}$ Judicial independence should not, therefore, be viewed as a set of minimal constitutional guarantees or mechanisms, but as a set of mechanisms designed to reduce "the number of relationships between judges and others which hinder or appear to hinder" their ability to support one or more of the

100 See e.g. CJ Friedrich, Constitutional Government and Democracy: Theory and Practice in Europe and America, 4th ed (Waltham: Blaisdell Publishing Co, 1968) ("The general principle of the independence of the judiciary", writes Friedrich, "has come to be universally accepted as a basic tenet of constitutionalism and government according to law".)

101 Wheeler \& Bermant, supra note 86 at 838. Also see Adam M. Dodek, "Judicial Independence as a Public Policy Instrument" in Dodek \& Sossin eds, Judicial Independence in Context, supra note 79 [need first page \#] at 300; Peter H Russell, "Toward a General Theory of Judicial Independence" in Peter H Russell \& David M O'Brien eds, Judicial Independence in the Age of Democracy: Critical Perspectives from Around the World (Charlottesville \& London: University of Virginia Press, 2001) [need first page \#] at 3 [Russell, "Toward a General Theory"]; Peter H Russell, "A General Theory of Judicial Independence Revisited" in Dodek \& Sossin eds, Judicial Independence in Context, supra note 79 [need first page \#] [Russell, "Revisited"].

102 John A Ferejohn and Larry D. Kramer, "Independent Judges, Dependent Judiciary: Institutionalizing Judicial Restraints" (2002) 77 NYL Rev 962 (arguing that independence and accountability aim at a well-functioning system of adjudication); Owen M Fiss, "The Limits of Judicial Independence" (1993) 25:1 U Miami Int'l Am L Rev 57 at 58.

103 See e.g. P R Verkuil, "Separation of Powers, the Rule of Law and the Idea of Independence" (1988) 30 Wm \& Mary L Rev 301 ; EM Salzberger, "A Positive Analysis of the Doctrine of Separation of Powers, or: Why Do We Have an Independent Judiciary?" (1993) 13 Int'l Rev L \& Econ 349; Redish, supra note 86; Burbank, "The Architecture" supra note 80; Ferejohn \& Kramer, ibid; Cheryl Saunders, "Separation of Powers and the Judicial Branch" (2006) 11 Jud Rev 337; Peter A Gerangelos, The Separation of Powers and Legislative Interference in Judicial Process: Constitutional Principles and Limitations (California: Hart Publishing, 2009) at 17 .

104 Verkuil, ibid at 309; and see Peter W Hogg, "The Bad Idea of Unwritten Constitutional Principles: Protecting Judicial Salaries" in Dodek Sossin eds, Judicial Independence in Context, supra note 79 [need first page \#] at 25 [Hogg, "Salaries"].

105 Russell, "Revisited", supra note 101 at 800. 
three values that I have identified. ${ }^{106}$ The relevant mechanisms consist not only in rules about secure tenure or judicial remuneration, but also things like a court's jurisdiction, its control over its own administration, and the hiring, promotion and firing of judges. ${ }^{107}$

A third feature of judicial independence that I believe is important is that it is a relative concept. Specifically, it is relative in the sense that it is not absolute: there can, for example, be greater and less degrees of autonomy between the state, courts and judges. As Russell explains, "there is no way in which judges can be totally disentangled from all powers and influences inside and outside the judiciary. Nor would we want such total separation." ${ }^{, 108}$ The various mechanisms used to define the relationships between judges, courts and the state should be viewed as supporting varying degrees of autonomy between them.

Based on the above, I suggest that judicial independence is better viewed as a kind of bundle of rules, guarantees and institutional mechanisms designed to preserve and enhance judges' and courts' abilities to adjudicate impartially, maintain a constitutional separation or distribution of powers, and uphold the rule of law. Although the rules and guarantees that go into the bundle are not infinitely variable, deciding which of them is necessary demands that one consider the more fundamental value courts and judges are supposed to support. This, in turn, requires one to consider how their respective abilities to do so are threatened or impaired. In my view, since a wide range of circumstances can interfere with judges' and courts' abilities to uphold the three fundamental values I have identified, there are many ways that judicial independence can be threatened or impeded.

\section{Judicial Independence in Canadian Constitutional Law}

\section{Historical and Textual Sources of Judicial Independence}

Most discussions concerning judicial independence in Canadian law trace the contemporary doctrine to the 1701 Act of Settlement. ${ }^{109}$ Although the idea that courts represented an independent source of authority has more ancient roots, the Act of Settlement was a watershed moment in the history of judicial independence. Prior to that time, a practice had grown among the Stuart monarchy of making judicial appointments at the pleasure of the Crown. ${ }^{110}$ The Act of Settlement led to the abolition of such "at pleasure" appointments and guaranteed common law judges tenure during good office, provided that their salaries were to be prescribed by law, and ensured judges could only be removed by joint address of parliament.

The foundation of judicial independence in contemporary Canada began with the passage of the British North American Act ${ }^{111}$ or as it is now known, The

\footnotetext{
106 Ian Greene, "The Doctrine of Judicial Independence Developed by the Supreme Court of Canada" (1988) 26 Osgoode Hall LJ 177 at 196 .

107 Victoria C Jackson, "Packages of Judicial Independence: The Selection and Tenure of Article III Judges" (2006) 95 Geo LJ 965 at 967.

108 Russell, "Revisited", supra note 101 at 801.

109 Act of Settlement, 1701 (UK), 12 \& 13 Will III, c 2, s 2. See Greene, supra note 106 at 182; W R Lederman, “The Independence of the Judiciary” (1956) 34 Can Bar Rev 769 at 770.

110 John Baker, English Legal History 4th ed (London: Butterworths, 1990) at 166.

111 British North America Act, 1886 (UK), 49-50 Vict, c 35.
} 
Constitution Act, 1867.112 The Constitution Act, 1867 contains several provisions that, in large measure, reproduce the Act of Settlement guarantees. First, the preamble of The Constitution Act, 1867, states that Canada is to have a Constitution "similar in Principle to that of the United Kingdom" which has been held to imply a commitment to judicial independence. ${ }^{113}$ In addition, section 129 of The Constitution Act, 1867, prescribes the continuance of all courts on the terms that existed prior to Confederation which, by then, included the Act of Settlement guarantees. ${ }^{114}$ Most significantly, the "Judicature Provisions" found in sections 96 to 100 of Part VII of The Constitution Act, 1867 contain operative provisions substantially identical to the Act of Settlement guarantees. ${ }^{115}$

The other important textual source of judicial independence in Canada is the Charter of Rights and Freedoms. The forgoing speaks only of The Constitution Act, 1867 and courts with original jurisdiction. With the advent of the Charter, this picture changed dramatically. Section 11(d) of the Charter grants: "[a]ny person charged with an offence.... a right to a fair and public hearing by an independent and impartial tribunal." $" 116$ As a result, the Constitution guarantees that any courts or tribunals exercising a criminal jurisdiction must also be independent. Since both the federal and provincial governments may create offences, ${ }^{117}$ the Charter extends a qualified requirement that any court or tribunal exercising a criminal jurisdiction have sufficient protections to ensure they are independent.

\section{The Doctrine of Judicial Independence in Canada}

The effect of both the Charter and Judicature Provisions of The Constitution Act, 1867 has been manifestly greater than might be suggested by the words of the constitutional texts alone. Prior to the enactment of the Charter, the Judicature Provisions of The Constitution Act, 1867 played a relatively muted role in the constitutional jurisprudence. The one exception to this observation is section 96 which grants the judicial appointment power to the Governor General in Council. Section 96 has long been considered one of the "three pillars" in Canada's "temple of justice". ${ }^{118}$ However, its role in the jurisprudence has largely been relevant to

\footnotetext{
112 Constitution Act, 1982, being Schedule B to the Canada Act 1982 (UK), 1982, c 11 [Constitution].

113 Reference re Remuneration of Judges, [1997] 3 SCR 3 at para 110 [Reference re Remuneration].

114 Upper Canada was the first to introduce good behaviour appointments in 1834. These same guarantees were extended to Lower Canada's judges when the colony united with Upper Canada under: The Act of Union, 1840 (UK) 3 \& 4 Vict, c 35. The Act of Union is also notable for having provided that judges could only be removed by joint address of both houses of the newly united Province of Canada.

115 Section 99 guarantees superior court judges security of tenure and states that "the Judges of the Superior Courts shall hold office during good behaviour." Section 100 provides financial security by requiring the Federal Parliament to pay the salaries and pensions of superior, district and county court judges.

116 Charter, supra note 2, s 11(d).

117 The provinces have jurisdiction under section 92(15) of The Constitution Act, 1867, supra note 116, to enact law with penal sanctions in relation to laws with valid provincial objectives. See e.g. Nova Scotia Board of Censors v McNeil, [1978] 2 SCR 662; Mann v The Queen, [1966] SCR 238, Smith v The Queen, [1960] SCR 776; Irwin Toy ltd v Quebec (AG), [1989] 1 SCR 927.

118 Toronto Corporation v York Corporation, [1938] AC 415 at 415.
} 
the assignment of powers to inferior courts and tribunals ${ }^{119}$ and the preservation of the judiciary's power to conduct judicial review. ${ }^{120}$ By the time the Charter was adopted, the Supreme Court had not yet developed a constitutional doctrine defining either the purposes or requirements of judicial independence.

The development of a comprehensive doctrine of judicial independence in Canadian law was prompted by the enactment of the Charter. Since that time, the Supreme Court has developed a robust constitutional doctrine that extends judicial independence well beyond any of the express provisions of the Constitution. ${ }^{121}$ In the process, the Supreme Court has, I would argue, adopted an approach to judicial independence that is broadly consistent with my own description of it as an instrumental concept intended to uphold a set of more fundamental values. In Reference re Remuneration of Judges, for example, Chief Justice Lamer summarized the purposes of judicial independence as follows:

Judicial independence is valued, because it serves important societal goals - it is a means to secure those goals. One of these goals is the maintenance of public confidence in the impartiality of the judiciary, which is essential to the effectiveness of the court system. Independence contributes to the perception that justice will be done in individual cases. Another social goal, served by judicial independence is the maintenance of the rule of law, one aspect of which is the constitutional principle that the exercise of all public power must find its ultimate source in a legal rule. ${ }^{122}$

Although Chief Justice Lamer describes judicial independence as serving "social goals", it seems clear that he is identifying its role in preserving certain fundamental constitutional values. In substance, the Supreme Court's position is that securing the judiciary's independence is necessary to ensure that judges are, among other things, capable of adjudicating impartially and upholding the rule of law. Elsewhere, the Supreme Court has held that judicial independence is necessary so that that the judiciary is able to act "as impartial umpire to resolve disputes between two levels of government as well as between governments and private individuals who rely on the [constitutional] distribution of powers." ${ }^{123}$

\section{The Essential Conditions of Judicial Independence}

Since 1982, the Supreme Court has also set about defining a set of rules and guarantees that it views as essential conditions for judicial independence. In the

119 See e.g. Reference Re Authority to Perform Functions Vested by Adoption Act, The Children of Unmarried Parents Act, The Deserted Wives' and Children's Maintenance Act of Ontario, [1938] SCR 398; Labour Relations Board of Saskatchewan v John East Iron Works, Ltd, [1949] AC 134; Reference re Residential Tenancies Act, [1981] 1 SCR 714; Massey-Ferguson Industries Ltd v Saskatchewan (Minister of Agriculture) [1981] 2 SCR 413; McEvoy v New Brunswick (AG), [1983] 1 SCR 704.

120 See e.g. Quebec (AG) v Farrah, [1978] 2 SCR 638; Crevier v Quebec (AG), [1981] 2 SCR 220.

121 Reference re Remuneration, supra note 113 at para 107.

122 Ibid at para 112.

123 Beauregard v Canada [1986] 2 SCR 56 at para 23 [Beauregard]. 
leading decision of Valente, ${ }^{124}$ Justice Le Dain held that there were three "core characteristics" or "essential conditions" of judicial independence; security of tenure, financial security and administrative independence. ${ }^{25}$ Le Dain J. held that these three conditions not only needed to be maintained in fact, but also had to be seen to be maintained by "a reasonable person who is fully informed of all the circumstances." ${ }^{126}$

Security of tenure is the first of the core guarantees of judicial independence. In Valente, Justice Le Dain defined security of tenure as the opposite of a system of appointment at pleasure. The Supreme Court has, however, never prescribed an overly specific form of tenure; instead, it has held that for tenure to be secure, judges must "be removable only for cause and that cause be subject to independent review and determination by a process at which the judge affected is afforded a full opportunity to be heard." ${ }^{\text {,27 }}$ One of the few decisions to discuss tenure is Genereux. ${ }^{128}$ At issue in that case was the federal government's power to create a system of military justice. Although the Supreme Court held that a system of military tribunals was permissible - and indeed explicitly contemplated by section 11(f) of the Charter - it held that the legislation then in place did not provide adequate guarantees of tenure. Because military judges were appointed on an ad hoc basis by the Judge Advocate General (an agent of the Executive), there was no objective guarantee that a judge's career would not be negatively affected by rendering decisions in favour of an accused. The result, according to the Supreme Court, was that the legislation raised the prospect of actual or perceived bias rendering the statutory scheme unconstitutional.

The second core condition of judicial independence is financial security. Financial security refers generally to the institutional structures and constitutional guarantees built up around the remuneration of judges. In Valente, Justice Le Dain held that "financial security" required that "a [judge's] salary and pension should be established by law and not be subject to arbitrary interference by the Executive in a manner that could affect judicial independence(...) $)^{, 129}$ The financial security component of judicial independence has been the subject of significant controversy and litigation. ${ }^{130}$ The most important post-Valente decision on financial security is Reference re Remuneration of Judges. There, the issue was the constitutionality of austerity legislation passed or proposed by several provinces which purported, among other things, to reduce the salaries of provincial court judges. In holding the proposed salary reductions were unconstitutional, the majority (per Lamer C.J.) explained that judicial independence required the relationship between the legislature, executive and the judiciary to be depoliticized. Although the Court did not prohibit governments from reducing the salaries of judges, it nevertheless held

\footnotetext{
Valente v The Queen, [1985] 2 SCR 673 at 684 [Valente].

30 See Hogg, "Salaries" supra note 104; Lori Sterling \& Sean Hanley "The Case for Dialogue in the Judicial Remuneration Process" in Dodek \& Sossin eds, Judicial Independence in Context, supra note 79 [need first page \#]. Also see Tsvi Kahana, "The Constitution as a Collective Agreement: Remuneration of Provincial Court Judges in Canada" (2003-2004) 29 Queen's LJ 445 at 452.
} 
that any proposal that touched directly on judicial remuneration needed to be reviewed by an independent financial compensation commission. ${ }^{131}$ In its subsequent decision in Provincial Court Judges' Assn. of New Brunswick, ${ }^{132}$ the Supreme Court explained that it was a "constitutional requirement that commissions be independent, objective and effective." ${ }^{133}$

The third of the guarantees identified in Valente is the court's administrative independence. This refers to what Justice Le Dain in Valente described as the minimal control courts must have "over the administrative decisions that bear directly or immediately upon the exercise of the judicial function". ${ }^{134}$ In Reference re Remuneration of Judges, the Supreme Court clarified that the court's administrative independence referred to the "narrow" aspects of court administration such as "the assignment of judges, sittings of the courts, and courts list, as well as the matters of allocation of court rooms and direction of the administrative staff engaged in carrying out these functions." $" 135$ Administrative independence does not, however, refer to financial and budgetary expenditures of the courts because these "do not bear directly and immediately on the exercise of the judicial function.. ${ }^{136}$ The Court, moreover, recognized that The Constitution Act, 1867 contemplates a shared responsibility over court administration that often requires "the heads of the judiciary ...to work closely with the representatives of the Executive(...) $)^{, 137}$

Although the Supreme Court has referred to the three conditions I have just canvassed as being essential to judicial independence, it is important to note the Court has also held that the conditions necessary for judicial independence evolve over time. ${ }^{138}$ As cases like Reference re Remuneration of Judges suggest, the doctrine is an evolving area of the law; it is also clear from the case law that the Supreme Court does not consider itself bound by the strict wording of the constitutional texts, or by a narrow interpretation of the three core conditions it identified in its early jurisprudence. As a whole, I consider the Supreme Court's jurisprudence consistent with my view of judicial independence as an instrumental concept that is intended to ensure that courts and judges are both able and seen to be able to adjudicate impartially, maintain the distribution of powers in Canada's Constitution and uphold the rule of law.

\section{THE INSTITUTIONAL LIMITS OF INDEPENDENT COURTS}

The relationship between inaccessible courts and judicial independence may not at first be obvious. At base, my claim is that the court's ability to uphold the three values underlying judicial independence is sometimes compromised when litigants cannot access courts or obtain legal representation. The reason it is compromised is because of two forms of "dependency" that I maintain have been

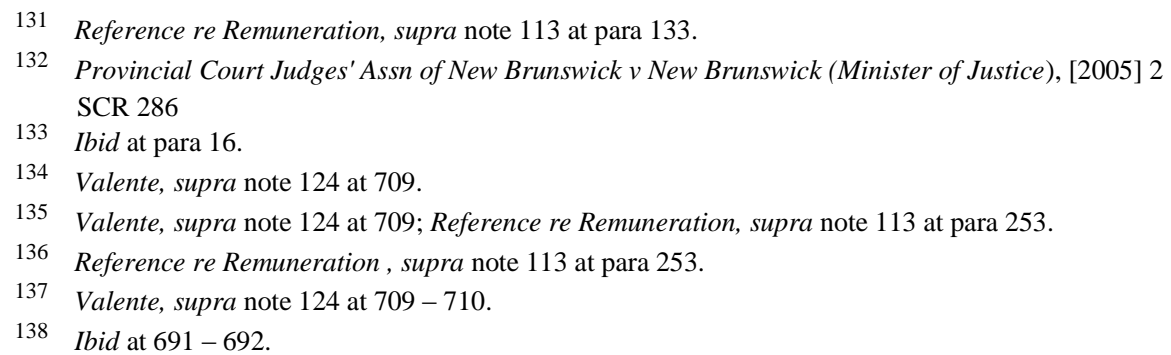


built into the rules governing adjudication in Canada. In the first place, I believe judges and courts are dependent on people to initiate legal proceedings in order for them to exercise their powers; and in the second place, they are dependent upon litigants to provide them with the evidence and legal argument they need to render decisions impartially. Although I accept there are good reasons the judiciary has been made dependent in these two ways, I also suggest that people's inability to access courts or obtain legal representation interacts with these forms of dependency in a way that undermines judicial independence. At the conclusion of this Part I suggest that Canadian courts can remedy the problems I identify by appointing state-funded legal counsel in appropriate circumstances.

\section{A. Unrepresented Litigants and Impartial Adjudication}

Impartiality is a preeminent value in most, if not all, systems of law and is widely viewed as one of the values at the heart of judicial independence. Often, however, the relationship between impartiality, adjudication and judicial independence is underspecified. ${ }^{139}$ I suspect that one reason explaining this is that many of us assume that impartiality is required of any process that can be justifiably called adjudication. Since in Canada it is accepted that judges have a duty to be impartial, ${ }^{140}$ I do not intend on disturbing this assumption; however, if the assumption is not unpacked, I think one is driven too easily to conclude that the specific rules governing adjudication in Canada are intrinsic to the process of adjudication and therefore, immutable.

Before I say more about this, I want to further develop my claim about the relationship between judicial independence and impartiality. Recall that in the last Part I compared judicial independence to a bundle of rules and guarantees designed to support three more fundamental values. As my claim relates to impartiality, I suggest that judicial independence should be viewed as a bundle of rules and guarantees designed to preserve and enhance a judge's ability to maintain an impartial attitude toward the outcome of a proceeding. I will explain more about what I mean by impartiality below; however, as I think this suggests, I do not accept the traditional view of judicial independence as being a core set of rules and guarantees that preserve judges from coercion by the state. In my view, a judge's ability to be impartial can be threatened by a variety of sources that are not connected to the state.

With this in mind, let me return to the meaning of impartiality. Impartiality has long been a subject of inquiry by moral philosophers. In its non-juridical form, impartiality refers to a requirement that individuals avoid allowing their evaluations of the moral rightness of human action "from being coloured by personal values, biases and inclinations as well as the contingent situation that individual happens to be in." ${ }^{141}$ Impartiality can be contrasted with moral partialism, a view that accepts that at least in some circumstances, it is permissible and even desirable for people to rely upon their biases and inclinations when

139 Greene, supra note 106 at 191 - 192. Also seeWilliam Lucy, "The Possibility of Impartiality" (2005) 25 Oxford J of Legal Stud 3 at 5.

140 Wewaykum Indian Band v Canada, [2003] 2 SCR 259 at para 58 [Wewaykum]. Also see Mugesera $v$ Canada (Minister of Citizenship and Immigration), [2005] 2 SCR 91 at para 13 [Mugsera].

141 Idil Boran, "On Distinguishing between Types of Impartiality" (2004) 38 J Value Inq 333 at 333. Also see Amartya Sen, "Open and Closed Impartiality" (2002), 99 J Phil 445 at 445 - 469. 
making decisions. $^{142}$ In both cases, the focus is on the mental attitude of a decision-maker vis-à-vis the thing she must decide and in turn, whether that decision-maker's decision can be coloured by having a personal stake in the outcome of the decision.

I do not want to stray too far into the philosophical debates about when decision-makers ought to be impartial. However, one way the philosophical discussions are helpful is in drawing one's attention to the fact that impartiality is a device that is used for making certain kinds of decisions. Few philosophers that I am aware of think that impartiality should be used for every sort of decision that one makes in life; many of the decisions one makes in life depend on one being partial. $^{143}$ More often than not, moral philosophers claim that impartiality should be used for making special decisions, such as those concerning the first order political or moral values that should govern our society. ${ }^{144}$

One area where most recognize that impartiality is necessary is in respect of the decisions made about people's legal rights and interests in courts. ${ }^{145}$ Of course, there are many reasons why one might want judicial decision-making about legal rights and interests to be impartial. These include things like fairness, equality, efficiency and accuracy, all of which come into play in designing both the substance of the law and the formalities of the legal process. ${ }^{146}$ But this judicial impartiality is not a spontaneous condition; it is an impartiality that is constituted and conditioned by a variety of legal rules, procedures and practices that govern and define the attitude of judges, as well as their roles in relation to litigants and the state.

In Canada, the rules that constitute judicial impartiality are found in the common law, the Constitution, and statutory rules governing adjudication. Among other things, these rules attempt to ensure that judges have and display an attitude of open-mindedness and an absence of pre-judgment when making decisions about peoples' legal rights and interests. Certain rules impose specific duties on judges to decide cases without actual bias. ${ }^{148}$ Other rules prohibit judges from

142 Ibid at 334

143 M Baron, "Impartiality and Friendship" (1991) 101 Ethics 836 at 837 (discussing the role of impartiality in personal relationships though ultimately arguing that impartiality does not require that we treat no one as special.)

144 John Rawls's theory of “justice as fairness" is one of the most famous examples. Rawls uses the impartial decisions of equal citizens who are placed in an "original position" in which they are ignorant of their statuses in the real world and who must decide on the rights and freedoms each will enjoy when this veil of ignorance is lifted. See John Rawls, A Theory of Justice (Oxford: Oxford University Press, 1971) (part III) .

145 See e.g. Jeremy Webber, "The Adjudication of Contested Social Values: Implications of Attitudinal Bias for the Appointment of Judges" in Appointing Judges: Philosophy, Politics and Practice: Papers Prepared for the Ontario Law Reform Commission (Toronto: OLRC, 1991) at 10 ; for an excellent summary of principles governing judicial bias in Canada see Paul M Perell, "The Disqualification of Judges and Judgments on the Grounds of Bias or the Reasonable Apprehension of Bias" (2005) 29 Advoc Q 102.

146 Webber, ibid at 8.

147 Lucy, supra note 139 at 4.

148 In Canadian law, the "reasonable apprehension of bias" has emerged as the criterion for evaluating bias. Therefore, it is not necessary to show actual bias: see Committee for Justice and Liberty v National Energy Board, [1978] 1 SCR 369 at 394; see also Newfoundland Telephone Co. v. Newfoundland (Board of Commissioners of Public Utilities, [1992] 1 SCR 623 at 638. 
participating in the proceeding in ways that might raise an apprehension of bias. ${ }^{149}$ Still, others govern procedure and define how the parties interact with one another and with judges. ${ }^{150}$ These rules are not only found in Canada's positive laws, but are also found in the ethical standards that govern the judiciary. ${ }^{151}$ I view this collection of attitudinal, role-related and procedural rules as together constituting what may be called impartial adjudication. Of course, impartial adjudication in Canada is not just any sort of adjudication, but is built around the adversarial model. ${ }^{152}$

I wish to add one qualification to the above. When I say that impartial adjudication is constituted by legal rules, I am not intending to suggest that impartial adjudication is simply what Canada's legal rules say it is. For a process to be impartial, I think it must meet some basic standards. If, for instance, a legal process were constituted in a way that clearly favoured one party over another, it could not, I think, be called impartial. As William Lucy writes, for a process to be impartial, it must "at a minimum, favour neither party to the dispute-cumcompetition or favour or inhibit both equally." ${ }^{153}$ He goes on:

[i]t is easy to imagine rules for the resolution of disputes that clearly disadvantage one party over another. Think, for example, of a situation in which some decision process either systematically ignored or accorded little value to views of one or other kind of disputant. Similarly, procedural rules or institutions that failed to take account of significant differences might include, for example, the inability of one or other disputant to speak the language in question or to fully understand what is going on.

One of the most forceful aspects of Lucy's observation is his claim that an impartial process may become partial, that is to say, biased, if it fails to account for significant differences between participants. In developing this point further, Lucy adds that a process that fails to account for differences between participants is not only unfair to them, but also has implications for decision-makers. Significantly, if a litigant is unable to participate in the process, Lucy claims that the decision-maker may be deprived of what he calls the "epistemic payoff" of hearing from both sides of the dispute. ${ }^{155} \mathrm{He}$ adds, moreover, that irrespective of whether there is an epistemic payoff, "when both parties...have a right to be

$149 R$ v $S(R D)$, [1997] 3 SCR 484 at paras $112-113$.

$150 \quad$ Ibid at para. 15.

151 Canadian Judicial Council, Ethical Principles for Judges (Ottawa: Canadian Judicial Council, 1998) at 44-45 ("[i]mpartiality is the fundamental qualification of a judge and the core attribute of the judiciary").

152 See e.g. $R$ v Swain, [1991] 1 SCR 933 at 947. Also see Borowski v Canada (AG), [1989] 1 SCR 342 at 358-5. This model is usually defined as having three characteristics: (1) an impartial judge with the jurisdiction to decide the dispute; (2) formal procedural rules governing the receipt and transmission of evidence and argument; and (3) the assignment of responsibility to the parties to present their own case and challenge their opponents' case.

153 Lucy, supra note 139 at 11.

154 Ibid.

155 Ibid. 
heard...this right serves to reduce the space for partiality or bias in decisionmaking."

The notion that a process that systematically ignores litigants would be unfair is recognized to some extent in Canadian law. For example, an accused in a criminal proceeding must be provided with a translator so that she can make full answer and defence. ${ }^{157}$ In Tran, the Supreme Court held that "for a hearing to be fair, a party who has difficulty with the language of proceedings must not only understand the proceedings, but must also be understood." held, would subject an accused to "a Kafkaesque trial which may result in loss of liberty." A similar value is arguably alive in Canada's historic constitutional guarantees recognizing the right to be understood by judges in both official languages. ${ }^{160}$ Yet even absent these specific constitutional guarantees, there is a sense, I suggest, that a judge would not be capable of being impartial if she were forced to give judgment completely ignorant of one party's "side of the story".

Although Canadian courts have developed some rules that attempt to address differences between litigants in criminal proceedings, by and large, the rules governing adjudication in Canada assume that litigants will be able to participate equally in the process. If they cannot, then it is also assumed that judicial impartiality will remain intact because of the various rules requiring that judges remain unbiased and otherwise open-minded. As a result, the rules governing adjudication largely ignore the fact there may be significant differences between litigants' abilities to participate and do not, therefore, account for how significant differences between litigants may affect the impartiality of the process.

To understand how a party's inability to participate in adjudication can increase space for partiality and bias, it is necessary for me to say something about adjudication as a form of social ordering. As Lon Fuller describes it, adjudication sits alongside other forms of social ordering like contract and popular elections ${ }^{161}$ and is "a way in which the relations of men to one another are governed and regulated." ${ }^{162}$ For Fuller, that which makes each form of social ordering different is not so much the roles assigned to participants, but the way people interact with one another in the process.

Unlike scholars who view judicial impartiality as being a product of the rules that govern the "office of the judge", ${ }^{164}$ Fuller claims that the interaction between disputants in the process of adversarial adjudication is what produces a judge's

156 As Lucy acknowledges, this last observation draws on Lon Fuller's powerful account of the role of party participation in adjudication which I take up below. See Lon L Fuller, "The Forms and Limits of Adjudication" (1978) 92 Harvard L Rev 353.

$157 \quad R v$ Tran, [1994] 2 SCR 951

158 Ibid at 975.

159 Ibid.

160 Reference re: Manitoba Language Rights, [1985] 1 SCR 721; Quebec (AG) v. Blaikie, [1981] 1 SCR 312; Macdonald v. Montreal (City of), [1986] 1 SCR 460; Bilodeau v Manitoba (AG), [1986] 1 SCR 449; $R$ v Beaulac [1999] 1 SCR 768.

161 Fuller, supra note 156 at $363-365$.

162 Ibid at 357

163 Ibid.

164 Compare Martin Shapiro, Courts: A Comparative and Political Analysis (Chicago: University of Chicago Press, 1986) at $1-17$. 
impartial attitude. Fuller illustrates his point by reference to the many decisionmakers called "judges" who must also make impartial decisions, but who do so in settings radically different from courts of law. Fuller maintains that what makes judges in adversarial adjudication different from other "judges" is the fact their "decisions are reached within an institutional framework that is intended to assure to the disputants an opportunity for the presentation of proofs and reasoned arguments." ${ }^{165}$ As he explains it, impartiality is the logical product of this institutional framework:

What generally occurs in practice is that at some early point a familiar pattern will seem to emerge from the evidence; an accustomed label is waiting for the case and, without awaiting further proofs, this label is promptly assigned to it. . . But what starts as a preliminary diagnosis designed to direct the inquiry tends, quickly and imperceptibly, to become a fixed conclusion, as all that confirms the diagnosis makes a strong imprint on the mind, while all that runs counter to it is received with diverted attention. An adversary presentation seems the only effective means for combatting this natural human tendency to judge too swiftly in terms of the familiar that which is not yet fully known. The arguments of counsel hold the case, as it were, in suspension between two opposing interpretations of it. ${ }^{166}$

Fuller's key point is that it is the parties' interactions that produce impartiality and not the individual judge's attitude; it is, he claims, in this adversarial setting that "impartial judgment can attain its fullest realization." ${ }^{167}$

Fuller's claim about the source of judicial impartiality is persuasive, though in some respects idealistic. The picture of adversarial adjudication that he paints is, I think, rarely achieved in practice. Fuller may, moreover, underestimate the importance of things like legal training in ensuring that judges are able to be impartial; he may also give too little weight to the legal rules that structure adversarial adjudication. ${ }^{168}$ At the same time, I would argue that even if one does not accept all of Fuller's argument, he is at least correct that the interactions between disputants in the course of adversarial adjudication are crucial to a judge's ability to be impartial.

Although Fuller did not directly address how significant differences in a disputant's ability to participate might impact on judicial impartiality, he does draw one distinction that suggests how this might distort the process he had in mind. Summarizing his views on the importance of the role of parties in adjudication, Fuller states that "[the] litigant must...if his participation is to be

165 Fuller, supra note 156 at 365.

166 Ibid at 383.

167 Ibid.

168 JWF Allison, "Fuller's Analysis of Polycentric Disputes and the Limits of Adjudication" (1994) 53 Cambridge LJ 367 at 376. Also see RG Bone, "Lon Fuller's Theory of Adjudication and the False Dichotomy Between Dispute Resolution and Public Law Models of Litigation" (1995) 75 BUL Rev 1273 at $1310-1315$. 
meaningful...assert some principle or principles by which his arguments are sound and his proofs relevant." "meaningful" participation, it seems clear that if a party's participation were not meaningful then a judge's ability to be impartial would be compromised. ${ }^{170}$

Fuller's account of judicial impartiality leads, in my view, to some troubling questions about the relationship between judicial impartiality and unrepresented litigants in Canada. Although I do not think one can speak of unrepresented litigants in overly simplistic terms, I do suggest that many unrepresented litigants are unable to participate meaningfully in the adversarial process and therefore, may open up greater space for partiality in the proceedings in which they are involved. However, unlike traditional sources of bias, this increased space for partiality does not arise from prejudgement or from a judge having a personal interest in the outcome of a proceeding; rather, the space for partiality and bias is increased because unrepresented litigants cannot produce the kind of dialogical interaction that Fuller had in mind.

At the same time, I would resist the suggestion that the increased space for partial decision-making produced by unrepresented litigants is merely an incidental result of Canada's rules of adjudication. As I claimed above, the rules governing adjudication in Canadian are not spontaneous, but have been shaped to achieve certain normative ends. However, they have been created in such a way that they fail to account for significant differences between litigants' ability to participate in the process. In effect, they have been developed in a way that favours those who are represented by lawyers. In addition, these same rules also require that judges remain passive and therefore, prevent judges from compensating for an unrepresented litigant's inability to provide them with the evidence and argument they need to be impartial.

The question this raises is whether there is any evidence that adjudication in Canada is less impartial vis-à-vis unrepresented litigants. It is difficult to demonstrate that there is a "structural bias" against unrepresented litigants in Canadian courts. However, the fact they consistently fare more poorly than litigants who are represented is well-documented. Many studies have demonstrated that, statistically speaking, unrepresented litigants lose more often in the same type of legal proceeding as compared to when they are represented. ${ }^{171}$ Although I do not think that every time an unrepresented litigant loses he or she is the victim of judicial bias, there is, I suggest, something suspect about a process that leads to such dramatically different outcomes for litigants.

169 Fuller, supra note 156 at 369.

170 Lucy, supra note 139 at 16. In an earlier discussion of the subject of adjudication, Fuller emphasizes that anything that impairs participation will impair the integrity of the process; he writes: "Adjudication is a form of social decision which is characterized by a peculiar mode of participation accorded to the affected party, this participation consisting in the opportunity to present proofs and arguments for a decision in his favor. Whatever impairs the meaning and force of that participation impairs the integrity of adjudication itself"; see Lon L Fuller, “Adjudication and the Rule of Law" (1960) Proceedings of the Am Society of International Law 1at 5 [Fuller, "Proceedings"].

171 Although few statistics are available for Canada, many empirical studies have been conducted in the United States that amply demonstrate that courts consistently rule in favour of people with representation. For a recent summary of the research in the United States, see Russell Engler, "Connecting Self-Representation to Civil Gideon: What Existing Data Reveal About When Counsel is Most Needed" (2010) 37 Fordham Urb LJ 37. 
I want to conclude this section by returning to my broader claim about the relationship between the increased space for partiality I have identified and judicial independence. If I am correct that the presence of unrepresented litigants increases the space for partiality, then I see no reason why an unrepresented litigant's inability to participate meaningfully cannot, at least at times, be viewed as an impediment to the judiciary's ability to support the value of impartiality. In my view, if Canada's rules of adjudication presuppose a certain kind of participation in order for judges to be impartial, then the bundle of rules, guarantees and powers that constitute judicial independence must reflect this need. As I will argue below, one way judges could address an unrepresented litigant's inability to participate meaningfully is by appointing state-funded legal counsel to represent him or her.

\section{B. The Separation of Powers and Access to Courts}

The separation of powers is the second of the values that judicial independence is often said to uphold. The idea that an independent judiciary is necessary to secure a separation of powers is particularly common in American scholarship on judicial independence. ${ }^{172}$ Of course, not all constitutional systems have adopted the kind of separation of powers prescribed by the U.S. Constitution. Westminster parliamentary systems such as those found in the United Kingdom and Canada put much less stock in the maintenance of a strict separation of powers. Nevertheless, even in Canada, courts have acknowledged the importance of securing judicial independence in order to ensure that the judiciary be able to assign legal powers to the different organs of the state and to the different levels of government.

The classic or "pure doctrine" of the separation of powers can be understood by reference to three propositions. ${ }^{174}$ The first holds that there is an institutional distinction between the legislature, executive and judiciary. The second is that the institutional distinction between the organs of the state corresponds to the function each performs. And the third is a normative claim that the organs and their functions ought to be kept separated. As concerns this normative claim, two sorts of justifications have usually been offered in support of maintaining a separation of powers. The first is a libertarian rationale that supposes that a constitutional separation of powers is necessary to prevent power from being concentrated in one organ of the state, a circumstance that might risk tyranny or despotism. ${ }^{175}$ The

172 The father of the American approach is Alexander Hamilton; see Alexander Hamilton, Federalist Paper No 78 The Federalist Papers, Terence Ball ed (United Kingdom: Cambridge University Press, 2003).

The Supreme Court of Canada has held that The Constitution Act, 1867, assigns to the judiciary the responsibility to act as "an impartial umpire to resolve disputes between two levels of government as well as between governments and private individuals who rely on the distribution of powers". See e.g., Beauregard, supra note 123 at para 27.

174 Maurice JC Vile, Constitutionalism and the Separation of Powers (United States: Liberty Fund, 1998 ) at 349. Also see Richard Bellamy, "The Political Form of the Constitution: the Separation of Powers, Rights and Representative Democracy" (1996) 44 Pol Stud 436 at 437.

175 This was the dominant rationale of the classical proponents of the idea of the separation of powers as found, for example, in the writings of Montesquieu, Locke and Hamilton. An independent judiciary played no role in Locke's conception of the separation of powers. Montesquieu, moreover, wrote that the "judging power should not be given to a permanent senate" but instead to juries: C S Montesquieu, The Spirit of the Laws, translated by AM Cohler, Miller, B \& Stone, H. (Cambridge: Cambridge University Press, 1989) at 158. 
second rationale is functional in nature; it holds that separating state organs and their functions contributes to a more efficient division of labour: since the executive can act with more dispatch than a legislative body, and whereas courts are better able to interpret and apply the law, it is desirable to allow each organ to be master of its own domain. ${ }^{176}$ More sophisticated functional descriptions, such as Ronald Dworkin's account, hold that courts are better at addressing questions of principle whereas government and legislatures are better at addressing broad questions of public policy. ${ }^{177}$

Much ink has been spilled on the theoretical and conceptual problems involved in maintaining a pure separation of powers. I have alluded to some of these difficulties in Part III, which include the practical and conceptual problems involved in completely separating judicial, legislative and executive functions. Gerangelos has described these debates as a "melee of conflicting imperatives and subtle categorizations" ${ }^{178}$ that pit strict formalist conceptions against more fluid functionalist accounts. However, as Vile has convincingly demonstrated, the implementation of a separation of powers varies significantly across jurisdictions and is probably impossible to implement in any pure form. ${ }^{179}$ Although more could be said about these disagreements, I think it is more useful to return to my earlier claim that the separation of powers corresponds to a different bundle of rules and guarantees than does the value of impartiality.

The separation of powers, as Vile explains, has "been most significant, both intellectually and in terms of its influence, on institutional structures." suggests, most accounts of the relationship between judicial independence and the separation of powers focus on the court's role in maintaining a set of institutional relationships. Viewed through the lens of the separation of powers, claims about judicial independence emphasize the need for a bundle of rules and guarantees that permit courts to define and demarcate the various powers and functions of the different organs of government and to exercise judicial power in relation to those differing organs. Such claims say very little, at least directly, about the need for impartiality.

With this in mind, let me move on to my main claim concerning the problem of inaccessible courts and the implications of this problem for the court's ability to maintain a separation or distribution of powers. Most discussions about the separation of powers say little about the relationship between the doctrine and the process of adjudication itself. Often, the judiciary's role in the separation of powers is described in terms of an abstract exercise of a countervailing or supervisory power. ${ }^{181}$ These descriptions of the role of independent courts, while

176 Bellamy, supra note 174 at 437.

177 According to Dworkin, the judicial task involves questions of "principle", that is, consideration of the competing rights of individuals or groups. This can be contrasted with questions of "policy" involving competing views of the collective good of the community as a whole. See Ronald Dworkin, Taking Rights Seriously (Cambridge: Harvard University Press, 1977) at 82 - 90.

178 Gerangelos, supra note 103 at 7; See also Peter A Gerangelos, "Interpretational Methodology in Separation of Powers Jurisprudence: The Formalist/Functionalist Debate" (2005) 8 Const L \& Pol'y Rev 1 at 12 [Gerangelos, "Formalist/Functionlist"].

179 Vile, supra note 174 at 175.

180 Ibid at 12.

181 Jeremy Webber, "Supreme Courts, Independence and Democratic Agency" (2004) 24 Legal Studies 55 at 62 . 
valuable, are, in some respects, distant from the concrete ways that courts exercise their power. Although judicial power is notoriously difficult to define, ${ }^{182}$ I think it is at least clear that it is exercised when courts give judgments following some process of adjudication. In this sense, judicial power is primarily declaratory in nature; and in most instances, courts are dependent upon the other branches of government voluntarily complying with, or enforcing, their rulings. ${ }^{18}$

Another way that courts are dependent is in their reliance on litigants to trigger the exercise of their power. In Canada, as in most common law systems, courts cannot initiate legal proceedings except in a narrow range of circumstances. ${ }^{184}$ As a result, a court's ability to exercise judicial power requires a live controversy that plays out in the context of an adversarial proceeding initiated by someone other than the court. ${ }^{185}$ There are, of course, many justifications for limiting the court's power in this way, including that it preserves the court's institutional legitimacy. Moreover, if judges were permitted to initiate proceedings, it is hard to imagine that they could remain "untainted by preconceptions about what happened and what its consequences should be." $" 186$

Whether or not one agrees that judges should be prohibited from initiating legal proceedings, I suggest that their inability to do so has important consequences for their role in maintaining a constitutional separation or distribution of powers. Specifically, I suggest that the judiciary's capacity to exercise a countervailing or supervisory power is impaired when people are unable to call on the court to exercise its power. For example, when, as in Canada, people cannot start legal proceedings, courts will be unable to exercise their power. When this happens, the relevant legal problem does not vanish; instead, the government is able to act without regard to any separation, allocation or distribution of powers in the Constitution.

Although I am under no illusion that there are vast numbers of Canadians who wish to advance constitutional claims based on the separation or distribution of powers, I do maintain that there are at least some people who are unable to do so. From my point of view, the important point to take from this is that people's inability to start lawsuits has direct consequences for the court's ability to uphold one of the values underlying judicial independence. As I will elaborate at the end of this Part, courts could in theory develop mechanisms that would ensure that litigants are able to commence and maintain legal proceedings, in part, as a means of ensuring the judiciary continues to maintain a constitutional separation or distribution of powers.

182 Gerangelos, "Formalist/Functionalist", supra note 178 at 12.

183 Of course, this aspect of judicial power has not gone unnoticed and led to Alexander Hamilton's famous description of the judiciary as the "least dangerous" branch. Because judges had "neither FORCE nor WILL, but merely judgment", Hamilton wrote, they depend upon "the executive arm even for the efficacy of its judgments." Hamilton, supra note 177 at 378. [emphasis in original?]

184 There are, of course, a few exceptions, such as ex facie contempt (Poje v. British Columbia (AG), [1953] 1 SCR 516) or in rare instances where the courts act ex mero motu because of a threat of some kind of actual or potential illegality (BCGEU, supra note 64).

185 Borowski v. Canada (AG), [1989] 1 SCR 342 at 358-5.

186 Fuller, supra note 156 at 385. 


\section{Institutional Resources, Judicial Independence and the Rule of Law}

The rule of law is the last of the three fundamental values that judicial independence is intended to support. Earlier in my paper, I expressed scepticism about some of the claims made concerning the relationship between judicial independence and the rule of law. In particular, I questioned the idea that the rule of law required judicial independence so that the judiciary could support things like democracy, human rights or equality. Although I do not dispute the important role the judiciary plays in supporting these values, it seems to me that if the rule of law requires judicial independence, then this requirement flows from something other than the substantive content of the rules that judges apply.

Although most definitions of the rule of law likely presuppose the existence of something like independent courts, it is notable that many of the most influential accounts of the rule of law make no reference to courts or the independence of the judiciary. ${ }^{187}$ These "norm-oriented" conceptions of the rule of law, instead, emphasize the form legal norms must take for the state to govern through law. ${ }^{188}$ These include requirements such as that laws must be general, public, nonretroactive, clear or intelligible, non-contradictory, possible to perform, constant over time, and that there be congruence between the declared rule and official action. $^{189}$

There are, however, scholars whose definitions of the rule of law emphasize the role of procedure "rather than the formal attributes of the determinate norms that are supposed to emerge from that process(...)", Albert Venn Dicey's classic description of the rule of law, for example, places "at least as much emphasis on the normal operation of ordinary courts as it did on the characteristics of the norms they [administer]." ${ }^{191}$ For Dicey, the rule of law requires, firstly, that "no man is punishable or can be lawfully made to suffer in body or goods except for a distinct

187 See e.g. Lon L Fuller, The Morality of Law (New Haven: Yale University Press, 1964) at 39 [Fuller, "Morality"]; John Finnis, Natural Law and Natural Rights (Oxford: Clarendon Press, 1980) at 270 - 285; Friedrich Hayek, The Road to Serfdom, 6th ed (New York: Routledge Classics, 2001) at 54.

188 Fuller, "Morality", ibid at 39. Fuller has an extended discussion of each criterion at 46-90.

189 Fuller has an extended discussion of each criterion in "Morality", ibid at 46-90. To be clear, I do not suggest that Fuller is a positivist or that his description of the Rule of Law is exhausted by his account of an "inner morality of the law". In his essay, "The Forms and Limits of Adjudication", Fuller seems to imply that adjudication is required by the rule of law because governance through law is a rational form of social ordering. In his earlier commentary on the subject, Fuller argues that adjudication and therefore, courts were integral to the rule of law: "When we move from a condition of anarchy to despotism toward something deserving the name of "the rule of law," one of the most important aspects of that transition lies in the fact that formal institutions are established guaranteeing to the members of the community some participation in the decisions by which their interests are affected"; see Fuller, "Proceedings", supra note 170 at 5.

190 Waldron, "Concept", supra note 18 at 8 (Waldron argues that our understanding of the rule of law should not only focus on the value of settled, determinate rules, but also on the procedural and argumentative aspects of the legal process). Waldron writes: "No concept of what law is will be adequate if it fails to accord a central role to institutions like courts, to their distinctive procedures and practices like legal argumentation. Conceptual accounts of law that only emphasize rules and say nothing more about legal institutions than that some institutions make rules and some institutions apply them are way too casual in their understanding of what a legal system is. They are like understandings of democracy that neglect the central role of elections." 
breach of law established in the ordinary legal manner before the ordinary courts of the land. ${ }^{192}$

Independent courts are also a feature of Joseph Raz's well-known description of the principles that make up the rule of law. For Raz, the virtue of the rule of law is instrumental and lies in its ability to ensure that laws are able to efficiently guide human behaviour. ${ }^{193}$ Of independent courts, Raz says that it "is the essence of municipal legal systems that they institute judicial bodies charged, among other things, with the duty of applying the law to cases brought before them(...)" ${ }^{194} \mathrm{He}$ goes on to claim that the rules governing the independence of judges must be guaranteed or else people will "only be able to be guided by their guesses as to what courts are likely to do-but these guesses will not be based on the law but on other considerations." $" 195$

John Rawls' substantive conception of the rule of law also includes a requirement for independent courts. Although Rawls did not view the rule of law as defining the substantive content legal rules, he did maintain that it required independent courts:

[t]he rule of law requires some form of due process: that is, a process reasonably designed to ascertain the truth, in ways consistent with the other ends of the legal system, as to whether a violation has taken place under what circumstances. For example, judges must be independent and impartial, and no man may judge his own case. ${ }^{196}$

What explains the relative unity among the differing conceptions of the rule of law and the requirement for independent courts? The main reason, I suggest, that most conceptions of the rule of law demand an independent judiciary is that the rule of law imposes conditions on how disputes about law are resolved. First, the rule of law requires independent courts (and therefore, rules about judicial independence) because it demands that disagreements about the meaning of law must be resolved impartially. Consider, for example, if rulers were to resolve disagreements according to their subjective views about the meaning or applicability of the rules they created. If this were so, people could no longer guide their behaviour according to the objective expression of legal rules, but would be left guessing at the rulers' unpublished intentions. Second, the rule of law also requires independent courts so that disputes about law can be resolved in a manner consistent with the overall objective of providing rules that can guide human behaviour.

Let me now turn to why I think this has implications for a legal system that is subject to the kinds of problems of inaccessibility that I described in Part II. Although the rule of law has often been advanced in support of claims about access to justice, many of these claims are made without much regard to its meaning. One exception to this observation is found in a paper by David

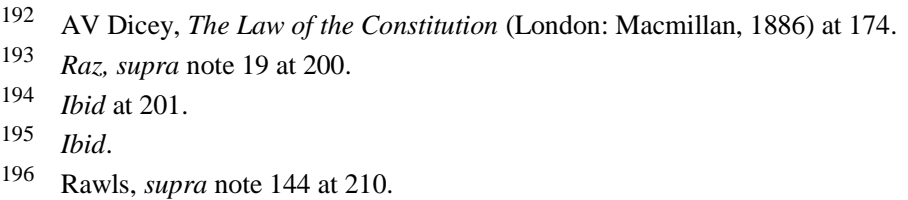


Dyzenhaus concerning the normative justifications for legal aid. ${ }^{197}$ Dyzenhaus argues that the rule of law may sometimes yield a kind of "implicit right" to statefunded legal counsel. ${ }^{198}$ In justifying his claim, Dyzenhaus points to the publicity condition found in Thomas Hobbes' austere account of legal governance under an uncommanded sovereign. ${ }^{199}$ Despite Hobbes' claim that there were no restraints on the kinds of laws the sovereign could make, Hobbes nevertheless maintained that the sovereign's laws had to be "perspicuous" and accessible to its subjects. ${ }^{200}$

Drawing on Hobbes, Dyzenhaus argues that the publicity condition-a condition found in every contemporary definition of the rule of law-requires not only that citizens be aware of their "legal entitlements", but also that they have "effective access to them." ${ }^{201}$ Dyzenhaus goes on to relate his claim about accessibility to the complexity found in the contemporary Canadian legal system. In his view, if a government has enacted laws that are so complex as to require lawyers to understand and rely upon them, then the publicity condition may also require the government to provide its citizens with lawyers. However, Dyzenhaus' claim is not that citizens have a moral right to lawyers; rather, the right to a lawyer is contingent upon the government's decision to enact laws that are inaccessible to its citizens without the assistance of a lawyer. ${ }^{202}$

In my view, Dyzenhaus' claim about the relationship between the rule of law and the right to counsel can be extended to the government's obligation to support courts and judges. I suggest that any government that wishes to rule through law cannot create a complex legal system unless it is prepared to provide judges and courts with rules, guarantees and resources necessary for them to render decisions impartially and otherwise consistent with the norm-oriented prescriptions of the rule of law. The obligations the rule of law imposes on governments to support courts and judges are diverse. Most obviously, the rule of law, as Raz argues, requires that governments must pay for judges' salaries and that they must enact rules and guarantees concerning judges' conditions of service. ${ }^{203}$ Think also of courthouses, law libraries, copies of statutes or access to legal databases. ${ }^{204}$ All of these are essential if judges are to render decisions that are correct, consistent, and predictable.

I also believe that in a complex system of law, such as found in Canada, the government must account for judges' ability to cope with unrepresented litigants.

197 David Dyzenhaus, "Normative Justifications for the Provision of Legal Aid" in Report of the Ontario Legal Aid Review: A Blueprint for Publicly Funded Legal Services (Toronto: Queen's Printer, 1997) at 475.

198 Ibid at 477.

199 Ibid.

200 Thomas Hobbes, Leviathan Richard Tuck ed (Cambridge: Cambridge University Press, 1997) at 239; Hobbes writes that the Sovereign must make laws that are "Needfull, for the Good of the People, and withall Perspicuous".

201 Dyzenhaus, supra note 197 at 477.

202 Ibid at 478.

203 Raz, supra note 19 at 201.

204 In the United States judges have occasionally ordered government to pay for the maintenance of underfunded court services to preserve their independence. See generally GG Webb \& K.E. Whittington, "Judicial Independence, the Power of the Purse, and Inherent Judicial Powers" (2004) 88 Judicature 12; See also JT Brennan, "Judicial Fiscal Independence” (1970) 23 U Fla L Rev 277. 
As I have already argued, judges' ability to remain impartial is challenged in proceedings involving unrepresented litigants. As I have said, judges do not get the same "epistemic pay off" from unrepresented litigants as they do from lawyers, at least in part because unrepresented litigants do not understand substantive law or the procedural rules governing the legal process. Also, because unrepresented litigants are unable to participate meaningfully in the process, they increase space for bias. In my view, this also represents a threat to judges' ability to uphold the rule of law.

The increasing numbers of unrepresented litigants in courts have other consequences for the rule of law. One of the risks that unrepresented litigants create is an increased likelihood that judges will make the wrong decision in a given case. Unlike lawyers, unrepresented litigants are less likely to draw relevant or conflicting legal authorities or legislation to a judge's attention. Although judges can partially compensate for this, they cannot completely make-up for the assistance they normally receive from lawyers. The result over time is that judges will make errors that will trickle down through the legal system, creating greater uncertainty, unpredictability and ultimately, undermining the law's ability to guide human behaviour.

I want to conclude this section by returning to my broader claim about the relationship between judicial independence and the rule of law. As I have claimed throughout, the bundle of rules that constitute judicial independence should include rules, powers and guarantees that preserve and enhance judges' abilities to uphold fundamental values like the rule of law. In my view, if the problems of inaccessibility I have described challenge judges' abilities to do so, then their independence is threatened or impeded. Although there are a variety of ways of correcting these problems, it seems to me that if one wishes to maintain the basic structure of our legal system, a simple way of doing so is to recognize that judges have a power and sometimes a duty to appoint state-funded counsel.

\section{Judicial Independence and the Power to Appoint State-Funded Counsel}

I want to now turn the question of whether it is open to Canadian courts to recognize that they have additional constitutional powers that would allow them to correct some of the problems of inaccessibility that I have identified. In Part II, I described the restrained approach the Supreme Court of Canada has adopted in relation to the right to state-funded counsel under the Charter. So far, the Supreme Court has only recognized an obligation on the government to provide litigants with lawyers in criminal and child protection proceedings under sections 7 and 11(d) of the Charter. The Supreme Court has never, at least directly, considered whether judicial independence might entail a positive obligation on the government to support access to courts.

As I have tried to demonstrate, the presence of increasing numbers of unrepresented litigants and related problems of inaccessibility sometimes pose problems for judges' abilities to uphold the values underlying judicial independence. Before I offer one way of solving this problem, let me first explain why, as a matter of doctrine, I believe it is open to Canadian courts to rely upon the doctrine of judicial independence. Recall in Part III I argued that in spite of the Supreme Court having identified certain "core" conditions of judicial independence, the jurisprudence is not settled and remains open to further change. I also argued that the Supreme Court's existing doctrine was broadly consistent 
with my description of judicial independence as an instrumental value intended to support a set of more fundamental values. Although the Supreme Court has given pride of place to the value of impartiality, it has also held that judicial independence supports the maintenance of a constitutional distribution of powers and the rule of law. More recently, the Court imposed a positive constitutional obligation on the government to create judicial financial compensation commissions. In my view, the jurisprudence suggests the Supreme Court is willing to impose positive obligations on the government under the rubric of judicial independence when circumstances suggest that the judiciary's independence might be threatened.

As I alluded to above, I believe one of the simplest ways that courts could address the problems of inaccessibility I have identified is by recognizing that judges have a constitutionally entrenched power to appoint state-funded legal counsel when it is necessary for them to support one or more of the values underlying judicial independence. In effect, this appointment power would be a new rule or guarantee that would be added to the existing bundle of rules, powers and guarantees that presently constitute judicial independence in Canada. What would my proposed appointment power look like? In contrast with a Charterbased right to counsel, the power to appoint legal representation based upon judicial independence would not be limited to proceedings involving the deprivation of life, liberty or security of the person. Nor would it require state action. Since judges must always be impartial and must strive to uphold the rule of law, ${ }^{205}$ there is no reason that an appointment power would be limited to certain kinds of legal disputes. The result, among other things, is that legal counsel could be appointed in a much broader set of cases than is currently the case.

This, of course, raises the question of when and how appointment power should be exercised. In my view, the decision to appoint counsel would be context-driven and would depend upon the nature of the dispute, its complexity and the capacity of the unrepresented litigants to participate in the process. Judges could appoint counsel on their own motion, or individual litigants could ask for counsel to be appointed. Having said this, I think the appointment power would be subject to important limitations. First, it could only be exercised in support of the proper resolution of a legal dispute; second, its exercise would be predicated on legal counsel being necessary to support judges' ability to be impartial, manage the constitutional distribution of powers, or uphold the rule of law. Third, the government would have an opportunity to justify why it should not pay for statefunded counsel and an opportunity to propose alternative measures short of the appointment of counsel. In this way, the appointment power I am proposing would be integrated into the judicial function and subject to a requirement of proportionality.

The significance of the appointment power that I am proposing lies mainly in its constitutional foundation. The common law has for centuries recognized that judges have a limited power to appoint amicus curiae to make submissions on points of law or fact in any legal proceeding. ${ }^{206}$ Traditionally, the appointment of an amicus has been viewed as discretionary power that flowed from court's

205 Wewaykum, supra note 140 at para 58. Also see Mugesera, supra note 140 at para 13.

206 Samuel Krislov, "The Amicus Curia Brief: From Friendship to Advocacy” (1962 - 1763) 72 Yale LJ 694 at 695. 
inherent jurisdiction, ${ }^{207}$ something that represents a significant point of departure from the power that I am proposing. For one thing, the court's inherent jurisdiction is not a constitutional power, but a kind of "reserve" fund of powers that "the court may draw upon as necessary whenever it is just or equitable to do so." ${ }^{208}$ For another, I suggest that when judges are unable to maintain one of the values underlying judicial independence, they do not simply have discretion to appoint counsel, but have a duty to do so. In fact, I would argue that a judge's failure to appoint counsel could constitute a reviewable error, particularly if it was evident that a judge required a party to be represented in order to be impartial.

While the appointment power I am proposing would sit on a constitutional footing, it would, like the common law amicus appointment power, be designed to be an "adaptable instrument for dealing with many of the problems that arise in adversarial proceedings." ${ }^{209}$ Amici have, for example, been appointed to assist litigants in effectively participating in the process when they could not do so otherwise. $^{210}$ Amici have often assisted the Supreme Court of Canada in constitutional cases. ${ }^{211}$ However, I am reticent to draw the analogy to the amicus too closely. My proposed power would be much broader and ultimately directed at supporting the ability of independent courts to maintain a set of very specific values.

\section{CONCLUSION}

In this paper, I have argued that people's inability to access courts or obtain legal representation gives rise to constitutional problems that transcend the rights and interests of individual litigants. As I claimed at the outset, much of the access to justice scholarship has emphasized how problems of inaccessibility affect the rights of individual litigants. Although I believe there are compelling reasons for adopting a "litigant-centric" approach, the jurisprudence reveals that courts have been unreceptive to individualized, rights-based claims. In view of this, I have suggested that it is unlikely that courts will recognize that litigants have a constitutional right to state-funded counsel unless they are provided with an alternative framework for analyzing the problem. I have argued that an alternative way of approaching the problem is by considering how problems of inaccessibility

207 Ibid at 696.

208 I H Jacob, "The Inherent jurisdiction of the Court" (1970) 23 Curr Legal Probs 23 at 28. Courts have occasionally suggested the inherent jurisdiction has a constitutional status, but largely, in my view, as a result of confusion between the court's "inherent jurisdiction" and its "ordinary jurisdiction". See e.g. $R v$ Cairenus, 232 CCC (3d) 13 (Ont Sup Ct). Recent appellate decisions recognize that the appointment of amicus imposes no obligations on the government; see: $R v$ Samra (1998), 129 CCC (3d) 124 (Ont CA); R v Russel, 2011 ONCA 303; and see $R v$ Martin, 2010 BCCA 526 ("A trial judge has the discretion to appoint an amicus curiae. However, if the amicus is to receive reimbursement, the Attorney General must agree to the appointment...")

209 Krislov, supra note 206 at 696.

210 Ibid.

211 See Miron v Trudel, [1995] 2 SCR 418 (where the parties agreed that an Ontario law that failed to extend accident benefits to unmarried partners violated section 15 of the Charter and could not be justified under section 1). Amici were also appointed for the Province of Quebec in Reference re Secession of Quebec, [1998] 2 SCR 217 and in Cooper v Canada (Human Rights Commission), [1996] 3 SCR 85 in order for there to be a contradictor on a question of jurisdiction. 
implicate the institutional capacity of independent courts to administer Canada's system of justice.

Approaching the issue from this perspective reveals that problems of inaccessibility not only interfere with individuals' rights and interests, but may also pose problems for the judiciary's independence. In arriving at this conclusion, I rejected the view that there is a single definition of judicial independence. Although certain scholars and courts have claimed that judicial independence can be defined according to a set of minimal standards or conditions, I suggested that such an approach to judicial independence does not fully account for the instrumental nature of the concept. Because judicial independence is a means to several ends, I argued that the exact rules and guarantees that constitute it vary according to the end or ends it serves. For this reason, I claimed that judicial independence is better viewed as a variable bundle of rights, powers and guarantees intended to support the judiciary's ability to adjudicate impartially, maintain a constitutional separation or distribution of powers and uphold the rule of law. This broadened view of the concept, I argued, also corresponds to a more expansive set of circumstances that may threaten or impede judicial independence.

Relying on my broadened definition of judicial independence, I argued that people's inability to initiate legal proceedings or obtain legal representation sometimes directly undermines the judiciary's capacity to support the three fundamental values judicial independence is supposed to serve. I suggested that the reason judicial independence was implicated was because of two forms of dependency that have been built into Canada's rules of adjudication. First, courts are dependent upon litigants to initiate proceedings in order to exercise their powers; and second, judges are dependent upon litigants' presentation of evidence and argument in order to remain impartial. Specifically, I argued that when litigants could not start legal proceedings, or could not participate meaningfully in the process, the judiciary was, for a variety of reasons, unable to support the fundamental values underlying judicial independence. In my view, these circumstances constitute a threat to judicial independence that can and should be corrected.

I do not believe there is a single way to remedy the many problems of inaccessibility that I have identified over the course of this paper. Nevertheless, I believe that at least some of the specific problems they pose for judicial independence can be corrected by recognizing that judges have a power and sometimes a duty to appoint state-funded counsel when it is necessary to support their independence. Unlike the appointment power already recognized under the Charter, the exercise of my proposed power would not be limited to criminal or child protection proceedings involving the state. As I explained in Part II, one of the most important limits on Charter-based claims for legal counsel is that they require claimants to show that their rights have been infringed as a result of state action. By instead focusing on the court's institutional capacity to support other fundamental constitutional values, it would be unnecessary for claimants to demonstrate that the government has directly interfered with their rights. Rather, the question is whether the court is capable of preserving one or more of the values that I have identified.

Canadian citizens' inability to access courts is one of the most important challenges facing Canada's legal system today. Although I do not consider that courts acting alone will be able to solve all of problems that currently plague 
Canada's legal aid system, I do believe that courts must establish a set of legal safeguards that will preserve their ability to maintain Canada's constitutional order. To effect a more significant change, it will ultimately be necessary for governments to renew their commitment to Canada's legal aid systems. Until governments do so, courts can and should be prepared to take action to preserve the overall integrity of the system of law they are charged with protecting. 